Külgazdaság, LXV. évf., 2021. július-augusztus (3-62. o.)

\title{
A nominális felzárkózás időben változó összetevői: reálgazdasági és árszintfelzárkózás az Európai Unióban 1995 és 2019 között OBLATH GÁBOR*
}

Az országok közötti jelentős fejlettségi különbségek árszintkülönbségekkel járnak együtt, és a fejlettségi szintek közeledését - a reálgazdasági konvergenciát - hoszszabb távon az árszintek közeledése kiséri. Bár az egy före jutó GDP-szintek piaci árfolyamon történö, vagyis nominális összehasonlitása alkalmatlan a fejlettségi különbségek és az országok közötti reálgazdasági közeledés kifejezésére, a relatív nominális szintek változásának reál- és árösszetevőre való felbontása megmutatja, hogy egy fejletlen ország nominális felzárkózása mennyiben származik abból, hogy az elóállitott javak egy före jutó mennyisége relative bövült, illetve abból, hogy a javak, azonos pénzben kifejezve, viszonylag megdrágultak. A relatív nominális változások az országok közötti keresztmetszeti, illetve időbeli összehasonlításra szolgáló statisztikák alapján egyaránt felbonthatók ár-, illetve reálösszetevőre, amelyek az Európai Unió (EU) több tagországára nézve eltérö jelzéseket adnak a viszonylagos ár-, illetve reálfelzárkózás alakulásáról. Az alternatív felbontások eredményei azonban megegyeznek abban, hogy az EU közép-és kelet-európai tagországainak gyors nominális felzárkózása 1995 és 2008 között nagyobb részben az euróban kife-

* Oblath Gábor a Közgazdaság- és Regionális Kutatóközpont Közgazdaságtudományi Intézetének tudományos fömunkatársa és a KOPINT-TÁRKI tudományos tanácsadója.

E-mail: oblath.gabor@krtk.hu

A tanulmány alapját képező kutatást az NKFI K-124808. számú, „Gazdasági növekedés, termelékenység és strukturális átrendeződés: az Európai Unió és Magyarország” címủ kutatási projektje támogatta.

A szerző köszönettel tartozik Berend T. Ivánnak, Bod Péter Ákosnak, Csillag Istvánnak, Györffy Dórának, Halpern Lászlónak, Hüttl Antóniának, Kónya Istvánnak, Krekó Juditnak, Madarász Aladárnak, Mihályi Péternek, Neményi Juditnak, Palócz Évának, Simonovits Andrásnak, Soós Károly Attilának és Surányi Györgynek az írás korábbi változataihoz füzött észrevételekért.

A kézirat első változata 2021. augusztus 2-án érkezett szerkesztőségünkbe.

https://doi.org/10.47630/KULG.2021.65.7-8.3 
jezett árszintfelzárkózáshoz (a valuták reálfelértékelödéséhez) köthető. A 2008 utáni időszak nominális elakadása a relatív árszintfelzárkózás megtorpanásának/megfordulásának tulajdonitható: a GDP/fö-vel mért reálfelzárkózás lassult ugyan, de nem állt meg.

Journal of Economic Literature (JEL) kódok: E01, F43, O47, O52.

Kulcsszavak: gazdasági fejlettség, reálgazdasági és árszint-konvergencia, nemzeti számlák, vásárlóerő-paritás, Európai Unió.

\section{Abstract}

\section{Components of nominal convergence: real economic and price level convergence in the European Union between 1995 and 2019 \\ GÁBOR OBLATH}

Significant cross-country differences in real income levels are accompanied by sizable differences in price levels, and, in the longer run, convergence in real income levels goes together with convergence in price levels. Although the cross-country comparison of nominal per capita GDP levels at current exchange rates is neither suitable to measure real income differences, nor their changes over time, their decomposition into a real and price component can reveal the contribution of the two factors to nominal convergence. The decomposition may be performed by drawing on two statistical sources, providing conflicting indications with respect to relative price and real changes in the case of several member states of the European Union. However, both sources suggest that the rapid nominal convergence of the Central and Eastern European member states between 1995 and 2008 mainly stemmed from the swift convergence in price levels (real exchange rate appreciation), while the deadlock in nominal convergence after 2009 is mainly due to the halt (reversal) in price convergence. Real economic convergence of the CEEU region continued in the 2010s, albeit at a slower pace.

Journal of Economic Literature (JEL) codes: E01, F43, O47, O52.

Keywords: economic development, real economic and price level convergence, national accounts, purchasing power parity, European Union.

\section{Bevezetés ${ }^{1}$}

Írásom a gazdasági konvergencia értelmezése, mérése és az Európai Unió (EU) tagországai közötti felzárkózás gazdag és napjainkban is gyorsan bővülö irodal-

1 Tekintettel a terjedelmi korlátokra, a cikkhez tartozó Melléklet (táblázatok és ábrák) és Függelék a következő linken érhető el:

https://kti.krtk.hu/wp-content/uploads/2021/04/mtdp2019_19_online-kiegeszitesek.docx 
mához kapcsolódik, amelyhez kétféle módon kíván hozzájárulni. Egyrészt azzal, hogy az országok, illetve országcsoportok közötti reálgazdasági felzárkózással összefüggésben és összehasonlításban vizsgálja az árszintfelzárkózás jelenségét. Másrészt írásom annyiban is igyekszik kiegészíteni a témában készült eddigi munkákat, hogy figyelmet fordít egy, a konvergencia irodalmában többnyire mellőzött értelmezési és mérési problémára: az országok közötti szint-összehasonlításokra szolgáló, vásárlóerö-paritáson (purchasing power parity, PPP) alapuló mutatószámok $^{2}$ változása - országonként és időszakonként eltérő mértékben - más jelzéseket adnak a reálgazdasági, illetve árszintfelzárkózás alakulásáról, mint az országok nemzeti számláin alapuló indexszámok összehasonlítása.

A reálgazdasági és az árfelzárkózás egymást kiegészítő folyamatainak kétféle szemléletủ adatbázis alapján történő vizsgálatának szándéka magyarázza, hogy a nemzetközi összehasonlítások legegyszerübb módszeréből, a piaci árfolyamon átszámított nominális mutatók egybevetéséből indulok ki. Amint kifejtem majd, az így értelmezett nominális összehasonlításokat sem az országok közötti fejlettségi különbségek, sem pedig a felzárkózás mérésére nem tartom alkalmasnak, ellenben jó kiindulópontnak tekintem a közgazdasági szempontból is értelmezhető reálgazdasági és árszintfelzárkózás vizsgálatához. Egyrészt azért, mert az utóbbiak a piaci árfolyamon mért nominális felzárkózás egymást kiegészítő összetevői, másrészt azért, mert az alternatív statisztikai források - eltérő módszerekre támaszkodva - ugyanazt a nominális felzárkózást osztják szét eltérő arányokban reál- és árösszetevőre.

Bár írásom közvetlenül nem foglalkozik a Magyarország felzárkózási teljesítményéről folyó diskurzussal, hazai nézőpontból is van üzenete. Az, hogy Magyarország pozíciója hogyan alakult a gyakori viszonyítási pontokhoz, például Ausztriához, Romániához vagy Szlovákiához viszonyítva, továbbá milyen volt a reál- és árfelzárkózás aránya egyes időszakokban, akárcsak az, hogy az elmúlt évtized hazai relatív teljesítményét hogyan látjuk a megelőző évtizedével összehasonlítva, erősen függ attól, hogy a keresztmetszeti (PPP-n mért) szintek változására, vagy a nemzeti számlák indexeire támaszkodva vonunk le következtetéseket.

Írásomban, a kisebb jelentésbeli különbségek ellenére, a közeledés, a konvergencia és a felzárkózás kifejezéseket azonos értelemben használom, mégpedig a

${ }^{2}$ A PPP az országok közötti keresztmetszeti volumen- és árszint-összehasonlítások statisztikai eszköze: azt mutatja, hogy valamely évben a külföldi valuta egységének vásárlóereje a belföldi valuta hány egységének felel meg. A fejlettségi szintek PPP-n történő összehasonlítása kiszüri az országok közötti árszintkülönbségek hatását, s ezzel reálértékek összehasonlítását teszi lehetővé. 
következő három összefüggésben. (1) Egy kevésbé fejlett ország (fejlettségi, illetve ár-) színvonalának közeledése egy fejlettebb országéhoz; (2) egy különböző fejlettségi szinteken álló országokból álló gazdasági régió (ilyen az EU) fejletlenebb csoportja - nevezetesen az EU közép- és kelet-európai (KKEU-i) térsége - átlagos szintjeinek közeledése az EU egészének átlagához; (3) az EU-tagországok szintjeinek általános közeledése.

A nominális gazdasági felzárkózás egy, a jelen írás céljai szempontjából értelmezett fogalom, amely a következőkben a folyó áron mért és piaci árfolyamon átszámított (euróban kifejezett) egy före jutó GDP-szintek közeledését jelenti. A nominális konvergencia kifejezést tehát a megszokottól (például az úgynevezett maastrichti nominális konvergenciakritériumoktól) eltérő értelemben használom: nem az inflációs ütemeknek és nem a nominális kamatoknak valamely referenciaszinthez való konvergenciájaként, hanem makrogazdasági aggregátumok azonos valutában, folyó áron mért szintjeinek közeledéseként. Mivel az is előfordul, hogy a nominális és az az árszintfelzárkózás terminusokat azonos értelemben használják (például Degler \& Staehr, 2021), hangsúlyozom, hogy ebben az írásban az árszintfelzárkózást a nominális konvergencia egyik - a reálkonvergenciát kiegészítő - összetevőjeként értelmezem.

Egy fejletlen és egy fejlett ország összehasonlításában csak akkor egyezhetne meg egymással a GDP/fö viszonylagos nominális és reálszintje, ha a két ország azonos valutában mért árszintje is megegyezne. ${ }^{3}$ Ennek megfelelően, csak akkor egyezhetne meg egymással a GDP/fö relatív változásaként értelmezett nominális és reálfelzárkózás mértéke, ha a közeledés során változatlan maradna a két ország egymáshoz viszonyított, azonos valutában kifejezett árszintje. Amint azonban látni fogjuk, a PPP-n alapuló nemzetközi árszint-összehasonlítások azt mutatják, hogy a fejletlenebb országok azonos valutában mért árszintje alacsonyabb a fejlettebbekénél, és arra is felhívják a figyelmet, hogy a fejletlen országok reálgazdasági felzárkózását hosszabb távon az azonos valutában mért árszintfelzárkózás, vagyis a felzárkózó országok valutáinak reálfelértékelődése kíséri.

Ezért a relatív nominális szintek, illetve változások önmagukban keveset mondanak, ellenben relatív ár- és reálösszetevőre való felbontásuk fontos információt nyújt arra nézve, hogy a gazdasági felzárkózás e két fontos metszete hogyan alakul egymáshoz viszonyítva. Ezt Magyarország Ausztriához viszonyított mutatóival

3 A külföldhöz viszonyított, külföldi valutában mért hazai árszintet a PPP és az árfolyam aránya mutatja. A PPP és az árszint jelentésével a következő szakaszban részletesen foglalkozom. 
A nominális felzárkózás időben változó összetevői: reálgazdasági és...

illusztrálom (az arányokat kifejező kerekített mutatókat használok; a pontosabb összehasonlítások a 4. szakaszban szerepelnek).

1995-ben Magyarország euróban kifejezett egy före jutó GDP-je Ausztria mintegy 16 százalékán állt. Ez azonban semmit sem mond Magyarország viszonylagos reálfejlettségi szintjéről, hiszen még nem ismerjük, hogy e nominális szintkülönbségnek mekkora része származott a két ország közötti árszintkülönbségből. Az Eurostat (2020) adataiból azonban megtudhatjuk, hogy 1995-ben a hazai GDP euróban kifejezett árszintje nagyjából Ausztria 40 százalékának felelt meg. Ez azért fontos információ, mert a relatív nominális szintet a relatív árszinttel elosztva jutunk a relatív reálszinthez, s így azt kapjuk, hogy a hazai GDP/fö Ausztriához viszonyított reálszintje ugyancsak 40 százalékon $(0,16 / 0,4)$ állt. A példa érzékelteti, hogy egy fejletlen és egy fejlett ország összehasonlításában a jelentős árszintkülönbség a reálgazdasági lemaradáshoz képest erősen felnagyítja a nominális szintkülönbséget, de azt is jelzi, hogy amíg a 40 százalékos relatív ár-, illetve reálszintnek egyaránt van közgazdasági jelentése, pusztán a 16 százalékos nominális relatív szintnek az ismerete téves következtetésre vezethet.

Hasonló a helyzet a relatív változásokkal. A PPP-adatok szerint 2019-ben a hazai GDP/fő reálszintje és a GDP euróban mért árszintje egyaránt Ausztria mintegy 60 százalékán állt, s így mindkét mutató relatív szintje 50 százalékkal $(0,6 / 0,4=1,5)$ volt magasabb, mint 1995-ben. Ezt közgazdasági elemzést érdemlő statisztikai információnak tekintem, ellentétben azzal, hogy a GDP/fö euróban mért relatív nominális szintje $(1,5 \times 1,5=) 2,25$-szorosára nőtt.

Az időbeli összehasonlításokat illetően azonban felmerül egy statisztikai-módszertani, egyszersmind közgazdasági értelmezési probléma: a PPP-n mért keresztmetszeti relatív ár- és reálszintek változása gyakran mást (egyes országok esetében nagyon mást) jelez, mint amit a nemzeti számlákból származó relatív árindexek (deflátorok) és volumenindexek mutatnak. Ehhez kapcsolódik írásomnak az a mondandója, hogy az országok közötti ár- és reálfejlettségi különbségek időbeli alakulá$s a-s$ így az ár- és a reálgazdasági felzárkózás folyamata - kétféle módon mérhető. Egyértelmúen csak a közgazdasági elemzéshez felbontásra szoruló nominális felzárkózás mérhető, ami viszont két különböző szemléletet tükröző és eltérő célokra szolgáló statisztikai forrás alapján osztható szét ár- és reálösszetevőre.

Magyarország és Ausztria példájához visszatérve, a nemzeti számlák adatai szerint 2019-ben, 1995. évi bázison, Magyarországon a GDP/fő volumenindexe megközelítően 1,4-szerese, a GDP euróban mért deflátora pedig 1,6-szorosa volt Ausztria megfelelő mutatóinak. A kettő szorzata, a relatív nominális változás természetesen 
ugyanúgy 2,25-szoros $(=1,4$ x 1,6) relatív emelkedés, mint a PPP-n mért mutatók esetében. A különbségek ismeretében azonban okkal merül fel a kérdés, hogy e relatív nominális változáshoz az ár- és reálfelzárkózás egyforma arányban járult-e hozzá (50-50 százalékos növekedési többlet, amint a PPP-n alapuló mutatók jelzik), vagy pedig - amint a nemzeti számlák ár- és volumenindexei mutatják - a relatív árszintemelkedésnek 60 százalékos, a relatív volumenváltozásnak viszont ennél kisebb, 40 százalékos relatív növekedési többlet volt a hozzájárulása.

A kérdésre adható egy statisztikai szempontból szabatos és egy, a közgazdasági intuícióhoz közel álló, de módszertani szempontból kifogásolható válasz. A szabatos válasz úgy szól, hogy a nemzetközi relatív ár- és reálszinteket PPP-n, a változásokat pedig ár- és volumenindexekkel mérjük. Az intuíció viszont azt súgja, hogy ha az egyik ország PPP-n mért GDP/fő szintje a másikhoz viszonyítva két időpont között 40-ről 60 százalékra nőtt, akkor az így értelmezett változásnak is lehet valamilyen - tisztázásra váró - értelme, és nem lehet eleve elutasítani a PPP-n mért relatív szintekben bekövetkezett változás figyelembevételét. Ezért kétféle módon bontom majd fel a nominális relatív változásokat, hangsúlyozva, hogy az egyik - a PPP-n alapuló - módszertani szempontból problematikus, a másik pedig - az ár- és volumenindexeken alapuló - megalapozottabb és általában megbízhatóbb. Amennyiben a kettő közötti eltérés kirívó mértékű, és erre nem találunk érdemi magyarázatot (amint utalok majd rá, egyfajta magyarázat lehet a cserearányok változása), akkor a PPP-n mért változást - mint például Szlovákia esetében - erős fenntartásokkal indokolt kezelni.

Röviden kitérek általam nagyra becsült hazai közgazdászoknak arra a véleményére, hogy a relatív fejlettségi szinteket, illetve a felzárkózást piaci árfolyamon átszámított (nominális) mutatókkal indokolt mérni. E véleménnyel szemben az a legfontosabb ellenvetésem, hogy a nominális mutatók felbontása nélkül sem a relatív reálfejlettségi szintekről, sem pedig azok változásáról nem rendelkezhetünk ismeretekkel. Az, hogy a nominális változás kétféle módon bontható fel, a reálgazdasági és árfelzárkózás mérése körüli bizonytalanságot jelzi, és arra hívja fel a figyelmet, hogy ezek a folyamatok - számos fontos makrogazdasági jelenséghez hasonlóan (például munkanélküliség, foglalkoztatás, béralakulás, háztartási jövedelem és megtakarítás, külső egyensúlyi pozíció) - alternatív statisztikák alapján mérhetők, amelyek jelzései olykor jelentősen különbözhetnek egymástól.

Írásom a makroszintű felzárkózáshoz kapcsolódó kérdések közül csak néhányat emel ki, és nem tér ki a konvergencia számos fontos vonatkozására. Nem foglalkozik a gazdaságszerkezeti és árarány-közeledéssel, a bérfelzárkózással, továbbá éppen csak érinti a munkatermelékenységi és a fogyasztási szintek közeledését. Az EU-n 
belüli konvergenciának ezekkel a vonatkozásaival korábbi írásokban foglalkoztam. ${ }^{4}$ Azt az ugyancsak fontos és a témához szorosan kapcsolódó kérdést is csak említem majd, hogy a relatív árszinteknek a fejlettségi szintekhez viszonyított alakulása mit jelent a reálárfolyam alul-, illetve túlértékeltségére nézve, és ez utóbbi hogyan hatott a reálfelzárkózási folyamatra az EU-tagországokban - ezzel Krekó és Oblath (2018 és 2020) alaposan foglalkozott. A mellözött kérdések közé tartozik a KKEU-i országok felzárkózási pályáinak összehasonlítása és a különbségek okainak vizsgálata ez például Oblath (2014b) és Győrffy (2021) tanulmányának a témája.

A reálgazdasági felzárkózásnak, azon belül az EU-tagországok közötti reálkonvergenciának hatalmas irodalma van, ${ }^{5}$ és az Európán belüli árszintfelzárkózással is számos írás foglalkozott. ${ }^{6}$ Nincs azonban tudomásom olyan korábbi munkáról, amelynek kifejezett céljai közé tartozott volna, hogy az általam nominális felzárkózásnak nevezett statisztikai jelenséget kétféle megközelítés alapján bontsa fel reál-, illetve árösszetevőre, és ennek alapján igyekezzen képet adni a gazdasági konvergencia két, egymást kiegészítő, időben változó metszetéről az EU-tagországok tapasztalatainak alapján. Bemutatom az eltérö megközelítések eredményeit, valamint a közöttük mutatkozó eltéréseket, de a lehetséges magyarázatok közül csak a cserearányok változását érintem. Az eltérések hátterének alapos vizsgálata túlmutat írásom keretein (a cserearányokon alapuló, részleges magyarázatról lásd az írás online Függelékét). ${ }^{7}$ Bár kitérek a relatív népességváltozásnak az egy före jutó GDP relatív növekedéssel mért reálkonvergenciára gyakorolt technikai hatására, nem foglalkozom azzal a szakirodalomban alaposan tárgyalt közgazdasági kérdéssel, hogy a népességváltozás és annak szerkezete hogyan hat magára a gazdasági növekedésre. ${ }^{8}$ Írásom bemutatja, hogy - akár PPP-n kifejezett mutatókkal, akár ár-, illetve volumenindexekkel mérünk - az EU-tagországok közötti nominális konvergencia hátterében eltérő relatív ár- és reálfolyamatok húzódnak meg az 1995 és 2008 közötti, valamint az utána következő, 2019-ig tartó időszakban. A folyó áron és árfolyamon

${ }^{4}$ A szerkezeti konvergenciáról és az árarányok közeledéséről lásd Oblath és szerzőtársai (2015) munkáját; a termelékenységi és bérkonvergenciával Oblath (2014a), a makrogazdasági jövedelmi - cserearány-változásokkal korrigált - felzárkózással Oblath (2019b) foglalkozott.

5 A témáról az elmúlt években megjelent számos írás közül az ECB (2015), Eichengreen (2019), Franks és szerzőtársai (2018), Alcidi (2019), valamint Matić és szerzőtársai (2020) munkáját emelem ki; az utóbbi a GDP/fő alakulásánál tágabban, jóléti indikátorok alapján értelmezi a reálkonvergenciát. A közelmúltban több hazai szerző is foglalkozott a témával (lásd Győrffy, 2021; Halmai, 2018 és Kónya, 2018).

${ }^{6}$ Lásd például Belka \& Devereux, 2013; Čihák \& Holub, 2005; Dobrescu, 2015; Dreger et al., 2007; Degler \& Staehr 2021.

7 https://kti.krtk.hu/wp-content/uploads/2021/04/mtdp2019_19_online-kiegeszitesek.docx

${ }^{8}$ Erről lásd: Batog et al., 2019; Peterson, 2017; Heady \& Hodge, 2009. 
(euróban) mért nominális mutatók szerint az első periódust a KKEU-i térség viharos felzárkózása jellemezte, ez azonban nagyobb részben az euróban mért gyors árfelzárkózáshoz (a GDP relatív árszintváltozásával mért reálfelértékelődéséhez) ${ }^{9}$ köthető; a reálgazdasági felzárkózás is számottevő, de lényegesen lassúbb volt. A második időszakban a nominális mutatók a KKEU-i térség felzárkózásának elakadására utalnak, holott csak az árfelzárkózás torpant meg (több országban a korábbi irányzat meg is fordult), miközben a reálfelzárkózás, lassabban ugyan, de folytatódott. Az általános irányzatokat tekintve viszonylag csekély eltérés mutatkozik a PPP-n mért mutatók, valamint a nemzeti statisztikák által jelzett folyamatok között, e mögött azonban nagyon jelentős az országok közötti heterogenitás. Kitérek a KKEU-i országok GDP/fö- és GDP-növekedésének összehasonlítására is, amiből kiderül, hogy a térség reálgazdasági felzárkózását jelző mutatóhoz - technikai értelemben - az EU kevésbé fejlett országainak relatív népességcsökkenése is számottevően hozzájárult.

Az írás három részből áll. Az első rész célja a témához kapcsolódó alapvető fogalmak tisztázása, és néhány fontos empirikus összefüggés bemutatása. A második, polemikus részben a felzárkózás piaci árfolyamon való mérése mellett felhozott érveket vitatva fejtem ki, hogy miért szükséges a nominális felzárkózás felbontása árés reálösszetevőre. A harmadik rész statisztikai összehasonlításokat és elemzéseket tartalmaz: először Magyarország fejleményeit Lengyelországhoz és Ausztriához viszonyítva mutatom be, majd a KKEU-i térség folyamatait az EU átlagához viszonyítva vizsgálom, végül az EU egészén belüli reálgazdasági és árszint-konvergencia irányzatairól adok kétféle megközelítés alapján képet. Az összegző részben értelmezem a statisztikai elemzések eredményeit, és jelzem a téma kutatásának további irányait.

\footnotetext{
9 Ebben az összefüggésben az árszintfelzárkózás voltaképpen a valutának a GDP-deflátor alapján mért reálfelértékelődését jelenti. A rögzített árfolyamrendszert működtető felzárkózó országokban (Bulgária és a balti országok, később Szlovénia és Szlovákia) ez csak úgy történhetett, hogy árszintjük gyorsabban emelkedett a fejlettebb országok árszintjénél. A rugalmas árfolyamú országokban a nominális árfolyamváltozásnak is jutott szerep: a nemzeti valutában mért relatív árszintemelkedés mértékétől elmaradhatott a nominális leértékelődés mértéke, vagy a nominális felértékelődés volt nagyobb a nemzeti valutában mért relatív árszint változásánál.
} 
A nominális felzárkózás időben változó összetevői: reálgazdasági és...

\section{Fogalmak, technikai és tapasztalati összefüggések}

A keresztmetszeti összehasonlításhoz szükséges fogalmak tisztázását és a közöttük fennálló technikai összefüggések ismertetését nemcsak azért tartom fontosnak, mert e nélkül nehéz lenne követni az írás statisztikai elemzéseiben használt kategóriákat, hanem azért is, mert tapasztalataim szerint a PPP alapján számított mutatók jelentése és használata körül sok a félreértés. Először a relatív ár- és reálszintek (változások) vizsgálatához tartozó fogalmakat definiálom, majd az EU-tagországok adatai alapján mutatom be az empirikus összefüggéseket.

\subsection{Fogalmak és technikai összefüggések}

Nemzetközi keresztmetszeti összehasonlítások: relatív nominális szint, vásárlóerő-paritás, relatív ár- és reálszint

Egy makrogazdasági aggregátum (például GDP, fogyasztás, beruházás) nominális szintje belföldi vagy külföldi valutában kifejezett értéket jelenthet. A nominális szinteknek önmagukban nincs jelentésük; valamilyen összehasonlításban, illetve dekompozíció révén válnak értelmezhetővé. Az összehasonlítás lehet keresztmetszeti (a mutató, árfolyamon átszámítva, hol áll más országokhoz viszonyítva), időbeli (belföldi, illetve külföldi valutában mérve hogyan változott egy korábbi időponthoz viszonyítva), és a kettő kombinációja (külföldi valutában mérve és más országokhoz viszonyítva hogyan változott egy időponthoz képest). A keresztmetszeti összehasonlításból indulok ki, később térek rá az időbeli összehasonlításokra.

Egy makrogazdasági mutatószám relatív nominális szintjén azonos valutában kifejezett, vagyis piaci árfolyamon átszámított nemzeti mutatók közötti arányszámot értek (például: 2019-ben Magyarországon az egy före jutó GDP euróban kifejezett értéke Ausztria 33 százalékának felelt meg). E nominális arányszám két öszszetevő, a relativ ár - és a relatív reálszint eredője. Ahhoz, hogy a relatív reálszintet megkapjuk, a relatív nominális szintből ki kell szürni a relatív árszint hatását. ${ }^{10}$

A relatív árszint meghatározásának statisztikai eszköze a vásárlóerö-paritás (PPP), amely egy sajátos keresztmetszeti árszintindex. A GDP-re vonatkozó PPP azt mutatja, hogy a hazai GDP belföldi pénzben kifejezett, belföldi árszintje mennyivel

${ }^{10}$ Sokféle nemzetközi összehasonlításhoz nincs szükség (vagy lehetőség) reálértékek egybevetésére (például költségvetési egyenleg, külkereskedelmi forgalom, külföldi müködőtőke-befektetések, az EU-forrásokból származó transzferek, stb.). Ilyenkor a nominális mutatóknak a nominális GDP-hez viszonyított arányára támaszkodnak az összehasonlítások. 
magasabb/alacsonyabb egy külföldi ország GDP-jének külföldi pénzben kifejezett, külföldi árszintjénél. ${ }^{11}$ A PPP intuitív módon azt érzékelteti, hogy ugyanazért az árukosárért, amely külföldön a külföldi pénz egységébe kerül, a hazai pénz hány egységét kell belföldön kifizetni. A PPP tehát olyan átváltási kulcs, amely - a piaci árfolyamtól eltérően - kiszüri az országok közötti árszintkülönbségeket, s ezzel reál(volumen-) összehasonlítást tesz lehetővé.

Például 2019-ben a GDP-t tartalmazó képzeletbeli árukosarat tekintve az osztrák euró egységének vásárlóereje 186 forintnak felelt meg, miközben éves átlagban az árfolyam 325 forint/euró volt (vagyis a forint átlagos vásárlóereje a hazai 57 százalékára (187/325) csökkenne, ha azt euróra átváltva Ausztriában kívánnák a képzeletbeli kosár megvásárlására költeni). Az egy före jutó GDP értéke Magyarországon nagyjából 4,88 millió forintot, Ausztriában 44800 eurót tett ki. Ha magyar GDP/ fó árfolyamon átszámított értékét (14 800 euró $=4,88$ millió forint/325) viszonyítjuk az osztrák mutatóhoz, akkor a már említett $(14800 / 44800=) 33$ százalékos relatív nominális szintet kapjuk eredményül. Ha viszont a PPP-n átszámított értéket (26 $000=4,88$ millió forint/186) mérjük az osztrák szinthez, akkor azt kapjuk, hogy a hazai GDP/fó relatív reálszintje (más terminológia szerint: relatív volumenszintje) Ausztria 58 százalékát érte el (26 000/44 800).

Pontosan ugyanerre az eredményre jutunk, ha a hazai GDP Ausztriához viszonyított relatív árszintjével, a GDP-re vonatkozó PPP, valamint az árfolyam arányával (186/325 = 57 százalék) defláljuk a relatív nominális szintet: a GDP/fö Ausztriához viszonyított relatív reálszintje természetesen így is 58 százalék $(0,33 / 0,57)$.

Mindebből a későbbiek szempontjából az a fontos, hogy a PPP segítségével keresztmetszeti összehasonlításban a relatív nominális szint a relatív árszint és a relatív reálszint szorzatára bontható. Az intuíció azt súgja, hogy két szám szorzata egy mindkettőnél nagyobb szám, ez azonban csak az egynél nagyobb számok szorzatára érvényes (lásd később a relatív növekedést jelző mutatókat). A kevésbé fejlett országoknak a fejlettebbekhez viszonyított ár- és reálszintjét jelző mutatók azonban kisebbek egynél, ezért szorzatuk, a nominális relatív szint, mindkét számnál kisebb. A szorzat és szorzók közötti tartalmi relációkat tekintve pedig azt érdemes szem előtt tartani, hogy az elsődleges statisztikai információ mindig a relatív nominális szint, a másodlagos a relatív árszint (illetve a PPP), a relatív reálszint pedig a kettő

11 A PPP azért sajátos, nem pedig valódi árszintindex, mert tartalmazza a különböző valuták közötti ármércék különbségeit is. Ez természetesen nem vonatkozik az azonos valutát használó országokra - így az euróövezet tagországaira -, amelyek esetében az egymás közötti PPP-k és az árszintindexek azonosak. A különböző valutákat használó országok közötti azonos pénzben kifejezett árszintindex a PPP és az árfolyam hányadosa. 
A nominális felzárkózás időben változó összetevői: reálgazdasági és...

hányadosa. Ha országok közötti összehasonlításban bármi okból problematikusnak tartjuk a reálszintekre vonatkozó adatokat vagy - amint szó lesz róla - azok változását, akkor mindig a PPP körül kell keresni a problémát, mivel a reálszintekre nézve nincsenek közvetlen megfigyelések.

A PPP (s így a relatív árszint) jelentésével és használatával kapcsolatban fontos hangsúlyozni, hogy a fentiekben a forintnak a GDP-re vonatkozó, az osztrák euróval szembeni vásárlóerő-paritása csupán példaként szolgált. Olyan, hogy a PPP nem létezik: a konkrét PPP-k ugyanis két dimenzióban is specifikusak. Egyrészt attól függően különböznek, hogy melyik országhoz (országcsoporthoz) viszonyítunk, másrészt az összehasonlított virtuális kosár tartalmától is függnek. Más a GDP-re vonatkozó hazai PPP, ha Ausztriához vagy például az EU átlagához viszonyítunk (2019-ben az előbbi összehasonlításban 186, az utóbbiban 213 forint volt a PPP), továbbá mindkét összehasonlításban különböznek egymástól a GDP-re vagy például a fogyasztásra, illetve a beruházásokra vonatkozó PPP-k, s így a relatív árszintek is. ${ }^{12}$

A PPP-t általában az országok közötti reálfejlettségi, illetve életszínvonal-különbségekben (egy före jutó GDP, illetve fogyasztás), vagy a nemzetgazdasági munkatermelékenységben (egységnyi munkabefektetésre jutó GDP) mutatkozó különbségek számszerüsítésére használják. Ha azonban az elemzőt netán a gazdaságok reálméretének összehasonlítása érdekli, erre is jól használható. Ennek jelentőségére még visszatérek.

A további statisztikai összehasonlításokban és elemzésekben használt valamenynyi PPP-n mért mutató forrása az Eurostat PPP-adatbázisa (Eurostat, 2020a). A PPP számításában az Eurostat alapvetően az International Comparison Program (ICP) módszertanát alkalmazza (lásd World Bank, 2021). Léteznek ettől eltérő módszerrel elóállított PPP-n alapuló adatforrások is, amelyek közül a világméretű részletes öszszehasonlításokat tartalmazó Penn World Table (PWT, 2021) a legismertebb, ennek az adatbázisnak az EU-tagországok relatív GDP ár- és reálszintjére vonatkozó becsléseit azonban nem tartom kellően megbízhatóknak. ${ }^{13}$

12 A különbségeket érzékeltetendő, a 2019. évi hazai relatív árszintre - a specifikus PPP-k és az árfolyam (325 forint/euró) közötti arányra - vonatkozó adatokat idézem Ausztriához, illetve az EU27 átlagához viszonyítva. GDP: 57, illetve 66 százalék; egyéni fogyasztás: 53, illetve 63 százalék; beruházás: 69, illetve 73 százalék. Ezek az arányok jól mutatják, hogy - ellentétben a valutaárfolyammal, amelyből egy valutával szemben (évi átlagban) csak egy van - PPP-kből annyi van, ahány ország és összehasonlítható tétel. A lényeg: minden országgal (térséggel) szemben és valamennyi tételre nézve a specifikus PPP-ket (relatív árszinteket) kell használni a reálszintek összehasonlításához.

${ }^{13}$ Elsősorban a PWT által becsült külkereskedelmi ár- és cserearányszintek megbízhatóságát illetően vannak kétségeim, erről részletesen lásd Oblath (2019a) tanulmányának 5. részét. Az ICP módszerét követve, az Eurostat nem becsül külkereskedelmi árszinteket, hanem azzal a technikai feltevéssel 
Időbeli nemzetközi összehasonlítások: relatív nominális és alternatív módon mért ár- és reálváltozások

Egy ország valamely makrogazdasági mutatójának (így az egy főre jutó GDP vagy fogyasztás) relatív nominális változásán a mutató árfolyamon átszámított (például euróban mért) változásának más országokéhoz viszonyított arányát értem. Többnyire azonban nem az euróban mért relatív változások az érdekesek, hanem például az, hogy mennyivel gyorsabban vagy lassabban emelkedett egy ország másokhoz viszonyított egy före jutó termelési, illetve fogyasztási volumene. Más (például árversenyképességi) elemzések szempontjából pedig az a kérdés lehet érdekes, hogy melyik országban emelkedtek nagyobb mértékben az azonos valutában kifejezett árak. Mindkétfajta kérdés megválaszolásához ár- és reálösszetevőre kell bontani a relatív nominális változást.

A relatív nominális változások tényezőkre bontásának látszólag kézenfekvő módja az előbb tárgyalt, PPP-n alapuló relatív ár- és reálszintek időbeli alakulásának összehasonlítása. Bár ennek a felbontásnak az eredményeit is be fogom mutatni, jelzem, hogy ez statisztikai-módszertani szempontból problematikus eljárás. A PPP-vel foglalkozó módszertani irodalom nyomatékosan hangsúlyozza: a PPP kifejezetten arra szolgál, hogy adott évekre nézve biztosítsa a legjobb nemzetközi keresztmetszeti ár- és reál-összehasonlításokat (lásd például Eurostat \& OECD, 2012:18). A PPP-n mért árszintmutatók elöállításának módszere nincs tekintettel az adatok időbeli öszszehasonlíthatóságára, ami egyebek mellett abból is kitünik, hogy évek között változnak az összehasonlított árukosarak, az alkalmazott relatív árak és a módszertan (aminek hatását az Eurostat csak három évre vezeti vissza). Ezért a PPP-n mért éves relatív ár- és reálszintek nem képeznek a szokásos értelemben vett idősort.

Az időbeli összehasonlíthatóság követelményének az felel meg, hogy a relatív nominális változásokat az azonos valutára (piaci árfolyamon) átszámított nemzeti árindexek (deflátorok) arányával bontjuk komponensekre: a relatív nominális változás, valamint az így mért relatív árváltozás hányadosaként adódik a relatív volumenváltozás. Természetesen ez a megoldás sem tökéletes, hiszen a nemzeti statisztikák árindexei (deflátorai) az egyes országokon belül igyekeznek biztosítani az időbeli összehasonlíthatóságot.

él, hogy az export és az import PPP-je megegyezik a piaci árfolyammal. Ez a feltevés befolyásolja az összehasonlítás eredményeit (erre visszatérek), de transzparens. A PWT külkereskedelmi ár- és cserearányszint-indexei sok esetben valószerütlenek, és változásuk az EU-tagországok többségére nézve semmilyen kapcsolatban sincs a tényleges külkereskedelmi ár- és cserearányindexekkel. 
A nominális felzárkózás időben változó összetevői: reálgazdasági és...

A statisztikusok azonban rámutatnak: nem létezik olyan tökéletes módszer (árindexformula), amely egyszerre felelhetne meg a legjobb keresztmetszeti, valamint a legjobb időbeli összehasonlítás igényének (lásd például Daglaard \& Sorensen, 2002; McCarthy, 2013). Ezért mindkét felbontás eredményeit érdemes megismerni és egymással összehasonlítva vizsgálni, szem előtt tartva, hogy a relatív változásokat illetően a relatív árindexeken alapuló dekompozíció módszertani szempontból megalapozottabb, és eredményei is megbízhatóbbak.

Az EU-tagországok többségét tekintve hosszabb távon nincs jelentős különbség a relatív nominális változások kétféle felbontásának eredménye között, de például Románia, Észtország és Dánia esetében a PPP-n mért keresztmetszeti szintek időbeli változása az egy före jutó GDP lényegesen nagyobb relatív reálnövekedését jelzi, mint a nemzeti számlák relatív volumenindexe. Szlovákia és Svédország esetében fordított a helyzet: a PPP-n mért relatív szintváltozás a nemzeti számlák mutatóinál lassúbb relatív növekedést jelez.

Mivel a kétféle módszer pontosan ugyanazt az euróban mért GDP/fö-változást bontja kétféle módon ár-, illetve reál- (volumen-) összetevőre, a PPP-n mért relatív ár- és reálváltozás szorzata azonos a nemzeti számlákból származó relatív ár- és volumenindexek által mért változások szorzatával. Ebből következően a PPP-n, valamint a volumenindexszel mért relatív reálváltozás közötti arány megegyezik az árindexszel, valamint a PPP-vel mért relatív árváltozás közötti aránnyal. (A formális levezetést lásd az alábbi keretes írás 3. pontjában.)

A relatív reálváltozás PPP-n, valamint relatív volumenindexszel mért arányát (= a relatív árváltozás relatív árindexszel, valamint PPP-n mért relatív árszintváltozással mért arányát) a továbbiakban röviden összetételhatásnak nevezem, amelynek pontosabb megnevezése összetétel-, relatív ár- és módszertani hatás lehetne, mivel e tényezők mindegyike hozzájárulhat a kétféle módon mért relatív változások közötti különbséghez. (Az összetételhatás arra utal, hogy eltér az árak keresztmetszeti és az időbeli összehasonlításra szolgáló árukosarak szerkezete.)

Bár írásomnak nem célja az összetételhatás magyarázata, röviden érintenem kell egy módszertani különbséget, amellyel a GDP kétféle módon mért relatív reálváltozása közötti eltérés összefüggésbe hozható. Arról van szó, hogy a PPP számításának az Eurostat által (is) alkalmazott módszere a külkereskedelmi cserearányok változását (az exportárindexnek az importárindexhez viszonyított arányát) reálváltozásként, a nemzeti számlák módszertana pedig árváltozásként kezeli. ${ }^{14}$ Ezért a cserearányok

${ }^{14}$ Ennek az az oka, hogy az exportra és az importra nem számítanak PPP-t, hanem azzal a technikai feltevéssel élnek, hogy a külkereskedelemre vonatkozó PPP és a valutaárfolyam megegyezik. A nemzeti statisztikák viszont számítanak export- és importárindexet. 
javulása a GDP PPP-n mért relatív reálváltozását felfelé, romlásuk pedig lefelé téríti el a nemzeti számlák volumenindexe jelezte változástól. (Erről részletesebben lásd Oblath [2020] cikkét és az online Függeléket.)

Az összetételhatást emellett számos (a hosszabb megnevezésben említett) tényező is okozhatja (ezekről lásd McCarthy, 2013), amelyek azonban nem szisztematikusak, és akár erősíthetik, akár tompíthatják egymás, illetve a cserearány-változás hatását. Mindenesetre az említett öt ország közül azokban, amelyekben a PPP-n mért relatív reálnövekedés hosszabb távon gyorsabb volt annál, mint amit a relatív volumenindex mutatott, javultak a cserearányok, azokban pedig, amelyeket fordított reláció jellemzett, a cserearányok hosszabb távon romlottak.

Mindezt azért fontos előrebocsátani, mert ha a PPP-n, illetve a nemzeti statisztikák szerint mért rövid távú relatív változások között extrém eltéréseket tapasztalunk, és a cserearány-mutatóban nem történt extrém változás, akkor okkal vonhatjuk kétségbe a PPP-n mért időbeli összehasonlitás megbízhatóságát. Példaként Szlovákia esetére hivatkozom (amire később visszatérek), ahol 2015 és 2017 között az EU27hez viszonyított PPP-n mért GDP-árszint - valószínüleg a keresztmetszeti összehasonlítás módszerében történt változás miatt - 68,4-ről 75,2 százalékra (10 százalékkal) emelkedett, miközben a GDP-deflátor 1,5 százalékos relatív árszintcsökkenést jelzett. A PPP-n mért árszint megugrása természetesen hatással volt a GDP/fó relatív reálszintjére is: Szlovákia az EU-átlag 78 százalékáról 71 százalékára került. A GDP volumenindexe azonban az EU27 átlagát tekintve 4,5 százalékos, Szlovákiában pedig 5 százalékos növekedést mutatott a két év alatt: az időbeli összehasonlításra szolgáló indikátorok szerint tehát szó sincs az ország visszacsúszásáról. Mivel időközben Szlovákia külkereskedelmi cserearányai mindössze 1 százalékkal romlottak, megállapíthatjuk, hogy nincs kézenfekvő magyarázat az extrém összetételhatásra (-10 százalék), ezért az ország PPP-n mért relatív mutatóinak időbeli összehasonlításából nem tanácsos következtetéseket leszürni. ${ }^{15} \mathrm{Az}$ alternatív mutatók között Szlovákia esetében tapasztalt, néhány év alatt bekövetkezett szétnyílás azonban viszonylag ritka.

Az alábbi keretes írás formálisan is definiálja az eddigiekben használt és a következőkben hivatkozott fogalmakat, továbbá áttekinti a közöttük fennálló technikai összefüggéseket. A PPP-statisztika alapján számítható változásokat rela-

${ }^{15}$ Egy, a PPP-n mért szintek időbeli összehasonlításából leszürt gyakori következtetés szerint Szlovákia az euró bevezetésének köszönheti, hogy 2010 és 2019 között a GDP/fő szintje az EU-átlag 76 százalékáról 70 százalékára csökkent. A 2010. évi szint és a relatív volumenindex kombinációjából (konstans PPP-n mérve, lásd a következő keretes írás 4. pontját) ellenben az következne, hogy Szlovákia szintje 76-ról 85 százalékra emelkedett. 
A nominális felzárkózás időben változó összetevői: reálgazdasági és...

tív volumenszint- (vagy reálszint-), illetve árszintváltozásnak, a nemzeti statisztikák alapján mért változásokat pedig relatív volumen-, illetve árindexnek (deflátornak) nevezem.

\section{Relatív szintek és változások: fogalmak és összefüggések}

Az alábbiakban $V_{y}$ a GDP/fö folyó áron mért értékét, „," (felső index) a külföldet, $P P P_{y}$ a GDP-re vonatkozó vásárlóeró-paritást, $E$ a valutaárfolyamot, $V L_{y}$ a GDP/fö PPP-n számított relatív reálszintjét, $N L_{y}$ pedig az árfolyamon számított relatív nominális szintjét jelöli.

\section{A relatív reálszint meghatározása}

\subsection{A relatív reálszint közvetlen meghatározása a vásárlóerö-paritással} (PPP-vel)

$y$ értéke belföldön, belföldi valutában: $V_{y}$

$y$ értéke külföldön, külföldi valutában: $V_{v}^{*}$

y vásárlóerö-paritása: $P P P_{y}=P_{y} / P_{y}^{*}(y$ belföldi árszintje belföldi valutában/y külföldi árszintje külföldi valutában: $y$ tekintetében a külföldi valuta egységének vásárlóértéke a belföldi valuta hány egységének felel meg)

y relatív reál- (volumen-) szintje: $V L_{y}=\frac{V_{y} / P P P_{y}}{V_{y}^{*}}$

1.2. A relatív reálszint közvetett meghatározása: a nominális relatív szint felbontása

$y$ értéke belföldön, külföldi valutában: $V y / E$ (ahol $E$ a valutaárfolyam: belföldi/külföldi valuta)

y relatív nominális szintje külföldi valutában: $N L_{y}=\frac{V_{y} / E}{V_{y}^{*}}$

y relatív árszintje külföldi valutában: $P L_{y}=\frac{P P P_{y}}{E}$

y relatív reál- (volumen-) szintje: $V L_{y}=\frac{N L_{y}}{P L_{y}}\left(=\frac{V_{y} / P P P_{y}}{V_{y}^{*}}\right)$ 
2. Relatív nominális változás (d) a bázisidőszak (t-1) és a tárgyidöszak (t) között:

$d N L_{y}=\frac{N L_{y(t)}}{N L_{y(t-1)}}$

Kétféle felbontás (eltérő tartalommal)

2.1. A keresztmetszeti relatív árszint változása (nemzetközi PPP-statisztikák) alapján $\left(d N L_{y}=d P L_{y} \cdot d V L_{y}\right)$

Keresztmetszeti relatív árszintváltozás: $d P L_{y}=\frac{P L_{y(t)}}{P L_{y(t-1)}}$

Keresztmetszeti relatív reálszintváltozás: $d V L_{y}=\frac{d N L_{y}}{d P L_{y}}$

2.2. A nemzeti statisztikákból származó relatív árindexek alapján $\left(d N L_{y}=d R D_{y} \cdot d Q V L_{y}\right)$

Az árindex (deflátor) belföldi valutában belföldön: $d D_{y}$ ( $y$ árváltozása $t-1$ és $t$ év között)

Az árindex (deflátor) külföldi valutában külföldön: $d R D_{y}^{*}$ árváltozása $t-1$ és $t$ év között)

Relatív árindex (deflátor) külföldi valutában: $d R D_{y}=\frac{d D_{y} / d E}{d D_{y}^{*}}$

Relatív volumenindex: $d Q V L_{y}=\frac{d N L_{y}}{d R D_{y}}$

3. A 2.1. és a 2.2. felbontás közötti összefüggés:

$$
d N L y=d P L_{y} \cdot d V L_{y}=d R D_{y} \cdot d Q V L_{y}
$$

vagyis a PPP-n mért relatív ár- és reálváltozás szorzata megegyezik a relatív ár- és volumenindex által jelzett változás szorzatával, és mindkét szorzat megegyezik a nominális változással. A két megközelítés ugyanazt a relatív nominális változást bontja kétféle módon relatív ár- és reálösszetevőre. Ebből adódik a következö összefüggés:

$$
\frac{d V L_{y}}{d Q V L_{y}}=\frac{d R D_{y}}{d P L_{y}}
$$

amely szerint a PPP alapján mért relatív reálszint változásának a relatív volumenindexhez viszonyított aránya megegyezik a relatív árindexnek a PPP-n mért 
relatív árszintváltozáshoz viszonyított arányával. Ezt az arányszámot nevezem összetételhatásnak. Az összetételhatás mutatószáma tehát egynél nagyobb, ha a PPP-n mért relatív reálváltozás nagyobb, mint amit a volumenindex jelez (= ha a relatív árindex nagyobb változást jelez, mint a PPP-n mért relatív árváltozás), fordított esetben pedig egynél kisebb.

4. Konstans PPP-n kifejezett relativv reál- és árszintek. Egyes elemzések szempontjából érdekes lehet, hogyan néznek ki a tárgyévi relatív reál-, illetve árszintek, ha azokat valamely referenciaév folyó PPP-jén mért relatív szinteknek, valamint a relatív volumenindexek, illetve deflátorok szorzataként számszerüsítjük. (Az OECD [2021] PPP-adatbázisa 2015. évi konstans PPP-n mérve is közöl relatív GDP/fö szinteket.) Ha a referenciaév ( $t-1)$, akkor $t$ évben a konstans $P P P-n$ mért relatív reálszint:

$$
Q V L_{y[t,(t-1)]}=V L_{y(t-l)} \cdot d Q V L_{y}
$$

Bár konstans PPP-n nem szokás relatív árszintet számítani, a reálszint analógiájára könnyen előállítható:

$$
Q P L_{y[t,(t-1)]}=P L_{y(t-l)} \cdot d R D_{y}
$$

A referenciaévben a folyó és a konstans PPP-n mért arányszám értelemszerüen megegyezik a tárgyévi konstans PPP-n mért reál-, illetve árszinttel, azonban erősen függ a referenciaév megválasztásától. Ezért a kétféle módszerrel számított keresztmetszeti szintek összehasonlításának általában nincs jelentősége, de a kétféle mutató által jelzett irányzatok egybevetése tanulságokkal szolgál. (Extrém különbségek esetén azonban a szintek összehasonlításának is van értelme - lásd Szlovákia példáját.) A későbbiekben tárgyalt úgynevezett béta konvergencia elemzése (PPP-n mért kezdeti szintek függvényében vizsgáljuk a nemzeti statisztikákból származó növekedési ütemeket) alapvetően a konstans PPP koncepciójára épül, és az úgynevezett szigma konvergencia (a relatív szintek szórásának változása) is vizsgálható ezzel a módszerrel.

A fentiekben a GDP/fö (y) illusztrációként szolgált. Ugyanezek az összefüggések a fogyasztás/före vagy a beruházás/före is érvényesek, de az utóbbi esetekben a tételek saját vásárlóerö-paritásával (illetve relatív deflátorával) kell nemzetközi összehasonlításokat végezni. A GDP PPP-je (deflátora) nem használható a GDP felhasználási komponenseinek összehasonlítására. 
2.2. A reálfejlettség, az árszint és a nominális fejlettség alakulása közötti tapasztalati összefüggések az EU-ban

Ha a valóságban teljesülne a vásárlóerőparitás-elmélet ${ }^{16}$ abszolút változatának predikciója, amely szerint az azonos valutában mért nemzeti árszintek országok között kiegyenlítődnek (érvényesülne az úgynevezett egységes ár elve), akkor a gazdasági fejlettség nominális és reálszintje megegyezne, és a nemzetközi reál-összehasonlításokhoz elegendő lenne a valutaárfolyamot használni. Az árszintek azonban különböznek, így szükség van PPP-re, de ha ezek a különbségek teljesen véletlenszerüek lennének, akkor a nominális és a reálfejlettségi szintek eltérése is teljesen esetleges lenne.

A Balassa (1964) által újraértelmezett vásárlóerőparitás-elmélet predikciója szerint viszont szisztematikus, mégpedig pozitív kapcsolat van az országok árszintje és fejlettségi szintje között. E Balassa-Samuelson-,,hatásként” ismert összefüggés, amelynek megnevezésére Samuelson (1994) a Penn-hatást javasolta ${ }^{17}$ (mérsékelt sikerrel), mára a nemzetközi gazdaságtan egyik alaptételévé vált.

Mivel a nominális szint tartalmazza az árszint hatását (a relatív nominális szint a relatív ár- és reálszint szorzata), az árszintet a reálszint függvényében célszerü ábrázolni. Ezt mutatja az 1. ábra, amely az EU-tagországokra nézve a 2019-re vonatkozó, az EU27 átlagához viszonyított mutatók alapján ad képet az ár-, illetve a nominális fejlettségi szinteknek a reálfejlettségi szintekkel való összefüggéséről.

Az árszint (az ábrán szürke pontokkal jelölve) és a PPP-n mért GDP/fö alapján értelmezett fejlettségi szint közötti szoros keresztmetszeti lineáris összefüggés (szürke trendvonallal jelölve) a Penn-hatás meglétét igazolja az EU-tagországok körében. Amint az ábrán látható lineáris egyenletből kitünik, az árszint koefficiense nagyon közel van az 1-hez: egy százalékponttal magasabb relatív reálfejlettségi szint nagyjából egy százalékponttal magasabb relatív árszinttel járt együtt 2019-ben. ${ }^{18}$

16 A vásárlóerőparitás-elmélet klasszikus kifejtéséről lásd Cassel, 1922. A vásárlóerőparitás-elmélet nem tévesztendő össze a statisztikai összehasonlítások eszközéül szolgáló vásárlóerő-paritással, amelyre éppen azért van szükség, mert a vásárlóerőparitás-elmélet predikciói nem teljesülnek a gyakorlatban.

${ }_{17}$ A javasolt elnevezés a Penn World Table-re utal, amely a világ legtöbb országára nézve tartalmaz adatokat az USA-hoz viszonyított, PPP-n mért egy főre jutó GDP és az árszint alakulásáról. Az adatok az országok széles körére nézve igazolják a fejlettségi szint és az árszint közötti pozitív összefüggést. Ennek az összefüggésnek egy lehetséges, a szektorok közötti termelékenységkülönbségen (és a termelékenység eltérő ütemü változásán) alapuló magyarázatát adta Balassa (1964) és Samuelson (1964). E magyarázat a Balassa-Samuelson-modell (Asea \& Corden, 1994). A jelenségnek azonban vannak más, kínálat-, illetve keresletoldali magyarázatai is, amelyekről Krekó és Oblath (2020) nyújt áttekintést.

18 Az EU-n belül lényegesen szorosabb a fejlettségi szint és az árszint közötti pozitív kapcsolat, mint ami világméretben tapasztalható; lásd erről Krekó \& Oblath, 2018. 
Ebből pedig egyenesen következik az, amit az ábra fekete keresztmetszeti trendvonala mutat: ugyanebben az évben a nominális fejlettség a reálfejlettségnek csaknem pontosan négyzetes függvénye volt. A koefficiensek 1 százalékon szignifikánsak, és az ábrán is látható determinációs együtthatók rendkívül magasak.

1. ábra

Az egy före jutó GDP euróban kifejezett szintje, illetve a GDP relatív árszintje (függőleges tengely), valamint a GDP/fö vásárlóerö-paritáson mért reálszintje (vízszintes tengely) közötti összefüggés az EU-tagországokban 2019-ben

(EU27 = 100 százalék)

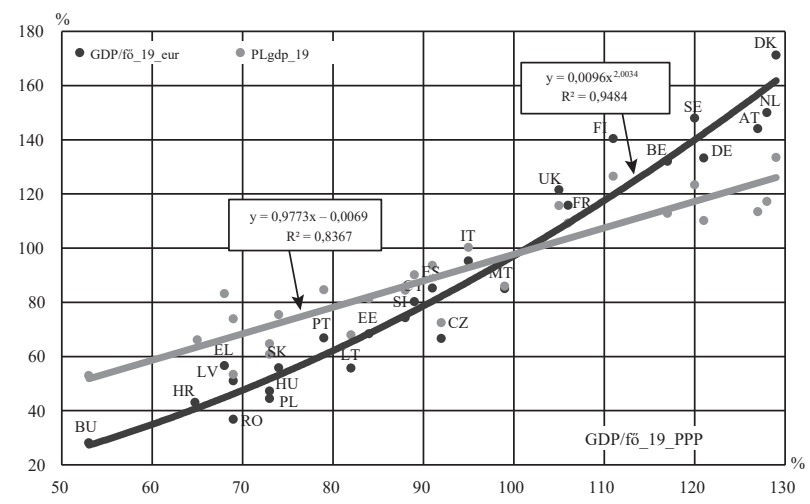

Forrás: Eurostat (2020a)

Ha más éveket választunk, vagy az 1995 és 2019 közötti időszak összevont adataira illesztünk trendet, kissé különböznek a koefficiensek, de a lényeg nem változik: az EU egészét tekintve a nominális szintkülönbséget a reálszintkülönbségeknek nagyjából a második hatványára növelik az árszintbeli különbségek. Az 1. ábrán látható, hogy az EU legalacsonyabb és legmagasabb fejlettségủ országa, Bulgária és Dánia esetében az EU átlagához viszonyított reálfejlettség, illetve relatív árszint nagyjából megfelelt egymásnak (kb. 55-55 százalék és 130-130 százalék); így az euróban mért szintjük az EU-átlag kb. 30, illetve 170 százalékán állt. Bulgária Dánia reálfejlettségi szintjének 42 százalékát érte el (Dánia szintje 2,4-szer volt magasabb), ám az euróban mért eltérés ezeknek az arányszámoknak a négyzete: Bulgária szintje 18 százalék, illetve Dánia előnye 5,6-szeres.

Az 1. ábra arra figyelmeztet, hogy a nominális szintkülönbség általában annál inkább torzít - fúvódik fel (inflálódik) - a reálszintkülönbséghez képest, minél nagyobb az árszintkülönbség, ami viszont a reálszintkülönbség függvénye. Az ábrán 
azonban az is látszik, hogy a reál- és a nominális szint közötti négyzetes ökölszabály csak a térség egészét tekintve érvényes, és csak véletlen, hogy a példaként említett két ország éppen a trendvonalon (annak közvetlen közelében) helyezkedik el. Amíg a 2008-2009. évi válság előtt az EU legtöbb KKEU-i tagországának relatív árszintje megfelelt relatív fejlettségének, vagy annál kissé magasabb volt (ez utóbbi fokozta a nominális összehasonlításból eredő torzítást), addig a 2010-es évek végén a legtöbb KKEU-i ország árszintje kissé alacsonyabb a reálfejlettségénél, de messze nem anynyival, hogy ez ellensúlyozza a nominális szintkülönbségek felfúvódását, s ennek a reál-összehasonlításokat torzító hatását.

A nominális összehasonlítások azonban nemcsak keresztmetszetben, hanem a hosszabb távú változásokat tekintve is jelentősen torzítanak: a fejletlenebb országok nominális felzárkózása annál nagyobb mértékü, minél nagyobb a reálfelzárkózást kísérő árszintfelzárkózás.

Az egy fóre jutó GDP euróban kifejezett szintjének, illetve a GDP relatív árszintjének változása (függőleges tengely) és a GDP/fő reálszintjének változása (vízszintes tengely) közötti összefüggés az EU-tagországokban 1995 és 2019 között, kétféle megközelítésben

(Az EU27 átlagához viszonyított évi átlagos növekedési ütemek százalékban) Bal oldali grafikon: PPP-n mért relatív ár- és reálváltozás; jobb oldali grafikon: relatív deflátorokkal és volumenindexekkel mért változás.
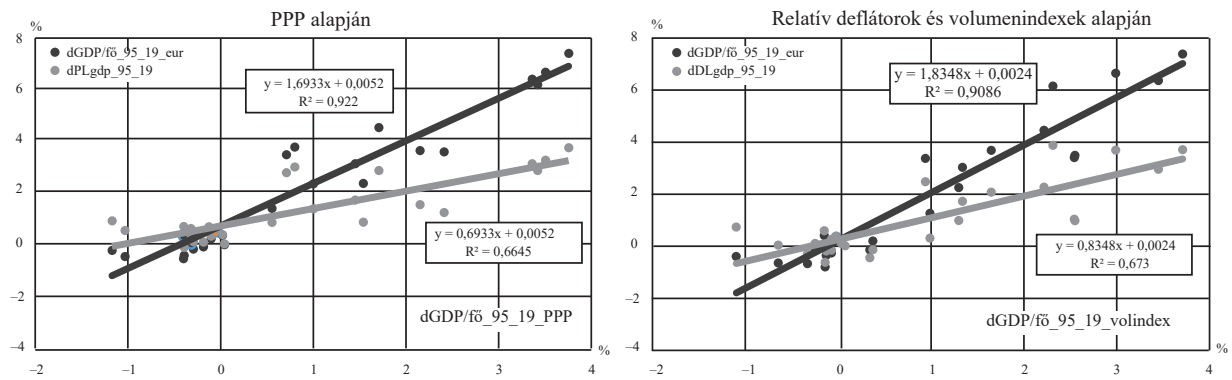

Jelölések: $d$ évi átlagos növekedési ütemeket jelöl az EU27 átlagához viszonyítva. dPL_gdp, illetve dRD_gdp: a GDP relatív árszintjének PPP-vel mért, illetve a relatív deflátorral mért változása.

Forrás: Eurostat (2020a, 2020b) alapján saját számítások.

A fentiekben a vásárlóerőparitás-elmélet abszolút változatának Balassa (1964) által adott korrekciójából indultam ki; a relatív változásokat illetően is az ő munkájá- 
ra hivatkozom. Írásában kimutatta, hogy a vásárlóerőparitás-elmélet relatív verziója - amely szerint az inflációs különbségeket az árfolyamváltozások kiegyenlítik - részben azért nem működik, mert a gyorsabban növekvő (felzárkózó) országok azonos valutában mért relatív árszintje hosszabb távon emelkedik (vagyis reálárfolyamuk felértékelődik). Amint a 2. ábrán látható, ezt a predikciót az EU-tagországoknak az 1995 és 2019 közötti időszak egészére vonatkozó tapasztalatai alátámasztják.

Amint szó volt róla, a GDP/fő euróban mért relatív növekedése (az ábrán fekete pontokkal jelezve) kétféle módon bontható ár-, illetve reálösszetevőre (lásd a fenti keretes írás 2. és 3. pontját): a PPP-n mért változások alapján (bal oldal) és relatív ár- és volumenindexekre támaszkodva (jobb oldal). A GDP euróban kifejezett relatív árszintváltozását mindkét oldalon szürke pontok jelölik. A kétféle felbontás alapján mutatkoznak ugyan különbségek, a lényeg azonban ugyanaz: a vizsgált időszakban viszonylag szoros pozitív összefüggés volt az árszintemelkedés és a GDP/fö reálnövekedése között az EU-tagországok körében.

\section{Egy számszaki összefüggés}

Mivel itt (relatív) növekedési ütemekről (az évek számával leosztott logaritmikus különbségekről) van szó, a nominális változás összetevői additívak: ha a GDP/fönek az EU-átlagához viszonyított 1 százalékponttal magasabb évi átlagos reálnövekedéséhez átlagosan $q$ százalékponttal magasabb relatív árszintemelkedés társul, akkor a GDP/fö nominális (euróban mért) relatív növekedési üteme átlagosan $(1+q)$ százalékponttal lesz nagyobb a GDP/fö reálnövekedésénél. A 2. ábrán látható regressziós becslések szerint az egy főre jutó GDP egy százalékponttal gyorsabb reálnövekedését nagyjából 0,7 (bal oldal), illetve 0,84 (jobb oldal) százalékpontnyi évi átlagos relatív árszintemelkedés, s így évi 1,7, illetve 1,84 nominális GDP/fő növekedés kísérte. Ebből egyrészt kiderül, hogy - az átlagos irányzatokat tekintve - a PPP-n mért árszintváltozás (bal oldal) a relatív nominális növekedésnek valamivel kisebb részét tulajdonítja relatív árváltozásnak, mint a nemzeti számlákból származó relatív deflátor (jobb oldal) - vagyis az előbbi valamivel nagyobb relatív reálváltozást jelez, mint az utóbbi. Másrészt a koefficiensek azt is mutatják, hogy 24 év alatt hatalmasra nőhet az átlagos reál- és nominális változás közötti különbség: 1 százalékpontnyi éves reálnövekedési többlet ennyi idő alatt 27 százalékkal nagyobb reáltöbbletet eredményez, ami a relatív árszintemelkedés hatására - az átlagot tekintve - nominális értékben mintegy a duplájára, 50-55 százalékra fúvódhat fel. 
Van azonban egy fontos különbség az 1. ábrán bemutatott keresztmetszeti és a 2. ábrán látható dinamikus tapasztalati összefüggés természete között. Amíg egyes években a jelentősen eltérő reálfejlettségü országok között az árszintek hozzávetőleg a reálfejlettségnek megfelelöen különböznek egymástól, és ezért bizonyos, hogy a nominális összehasonlítások felnagyítják a reálkülönbségeket, addig a változásokat tekintve az összefüggés egyrészt lazább (vesd össze az ábrákon szereplő R-négyzeteket), másrészt csak hosszabb távon (esetünkben mintegy negyedszázad fejleményeire nézve) érvényes. Így lehetséges, hogy egy hosszabb periódus egyik szakaszában az árszintemelkedés mértéke megelőzi a GDP/fö reálnövekedését, egy következő időszakban viszont lemarad attól, vagy akár negatívvá is válik. Amint látni fogjuk, ez a kép meglehetősen jól tükrözi az EU-n belüli felzárkózás 1995-től 2019-ig tartó időszakának két részperiódusát.

Mindebből pedig az következik, hogy az időbeli összehasonlitásokat tekintve időszakoktól és országoktól (országcsoportoktól) függően változhat a nominális és a reálmutatók egymáshoz viszonyított alakulása, ezért rövid és középtávon egyes felzárkózó országokra (vagy azok csoportjára) nézve még csak azt sem lehet megjósolni, hogy a nominális indikátor felfelé vagy lefelé torzít a reálmutatóhoz képest. Ez megerősíti, hogy a közgazdasági elemzéshez a nominális relatív változásokat ár- és reálösszetevőre kell bontani. Az, hogy e felbontás kétféleképpen végezhető el, csak alátámasztja a felbontás szükségességét: így válhat explicitté az ár-, illetve reálváltozások mérése körüli - a nominális összehasonlítás által elfedett - bizonytalanság mértéke.

\section{Polemikus kitérő: mit mutatnak és mit fednek el a nominális összehasonlítások?}

Az előző áttekintésből kiderült, hogy a nominális összehasonlítások keresztmetszetben a reálfejlettségi szintkülönbségeket, időben pedig azok változását nagyíthatják fel, de ismerjük meg azokat a megfontolásokat is, amelyeket a fejlettségi szintek és változások nominális összehasonlításában bízó közgazdászok - nem tudományos publikációkban - fogalmaztak meg.

Csillag István és Mihályi Péter(2020) a Külgazdaság körkérdéséreírott válaszukban - szándékuk szerint - az EU közép- és kelet-európai tagországainak Ausztria szintjéhez történt konvergenciáját vizsgálták. Az írásban a KKEU-i tagországok nominális GDP-idősorait (nem egy före vetítve) viszonyították Ausztriáéhoz, és ennek alapján jutottak arra a megállapításra, hogy 2008-ig rendkívül gyors volt, azt követően azon- 
ban elakadt a térség gazdasági felzárkózása. Nemcsak a nominális összehasonlítások miatt tartom a szerzők megközelítését aggályosnak, hanem azért is, mert csak a gazdaságok relatív méretének alakulása alapján vonták le következtetéseiket, és nem tértek ki az egy före jutó GDP-vel mért relatív fejlettségi szintek alakulására.

Az állítást, a módszert és a magyarázatot illetően három részt emelek ki a szerzők írásából (valamennyi kiemelés az enyém).

Az állitás: „Ha [...] kelet-európai perspektívában nézzük a dolgokat, akkor kiderül, hogy a rendszerváltás első két évtizedéhez képest, 2008 és 2018 között, Ausztriát benchmarknak tekintve, majdnem mindenütt megszünt a felzárkózás, vagy csak néhány tizedszázalékpontnyi volt."

A módszer: „A szokásoktól eltérően nem egy före visszaszámitott adatokkal dolgozunk, hanem folyó áron és árfolyamon USA dollárra váltott nemzeti adatokkal (forrás: Világbank). Nem az életszínvonal, azaz az 1 fóre esö fogyasztás alakulását vizsgáljuk, hanem az országok éves teljesitményét, ami kedvezö esetben értelemszerüen az éves GDP növekedését jelenti."

A módszer magyarázata: „Ez azért izgalmas, mert így a népességcsökkenés, és ezen belül a kivándorlás hatása is megjelenik, illetve a humán tőke »romlása« is, hiszen a legtermelékenyebb diplomások és a leginkább kalandvágyó és kalandtürő munkások mennek el az országból. Az is fontos eltérés a szokásos, EU-n belüli öszszehasonlításoktól, hogy az általunk átvett GDP-adatok piaci árfolyamon kerültek átszámitásra dollárra. Azaz, kissé leegyszerüsitve azt vizsgáljuk, a külföld »szemében « mennyit ér mindaz, amit egy naptári évben Magyarországon megtermeltünk."

Reflexióim a népességváltozás hatásának mellózéséhez és a piaci árfolyam alkalmazásához kapcsolódnak. ${ }^{19}$

A szakmai konszenzus szerint a GDP más országokhoz viszonyított hosszabb távú változása nem a relatív fejlettségi szint alakulásának, hanem a gazdaság relatív méretváltozásának az indikátora. Mivel a folyó áron kifejezett méretkülönbségek alakulása a relatív ár- és volumenváltozás együttes hatását tükrözik, a mért különbségeket (változásukat) az árszintkülönbségek (változásaik) kiszürésével, reálértéken indokolt mérni. ${ }^{20}$

19 Egyes nemzetközi összehasonlításokhoz a piaci árfolyamot kell használni (például az export piaci részesdésének alakulása, egy régióba történő tőkebeáramlásban való részesedés, stb.), de a relatív fejlettség alakulása nem tartozik ebbe a csoportba. Hangsúlyozom, hogy csak az adatok kezelésével és értelmezésével van gondom, a szerzők végső megállapításával ugyanis tökéletesen egyetértek: ,[k] i kellene lépni abból a hosszú évszázadok óta követett - bár sokak szeme előtt rejtett - keréknyomból, amit a humán tőke fejlesztésére fordított erőfeszítések, az átlátható állami pénzkezelés hiánya, a jogállamiság, az adófizetők pénze kíméletének a hiánya jellemez”.

${ }^{20}$ Az Eurostat \& OECD (2012) módszertani útmutatója a PPP-k lehetséges alkalmazásai közül az első helyen említi a gazdaságok méretének összehasonlítását (2012:14). 
A Maddison Project Database (MDP, 2020), ${ }^{21}$ amely közel 170 országra nézve tartalmaz messzire visszatekintő, PPP-n mért GDP- és népességadatokat, arra is felhívja a figyelmet, hogy a világnak sok olyan szegény országa van, amelyek gazdasági mérete az elmúlt negyedszázadban nőtt a fejlettebb országokhoz viszonyítva, de népességük relatíve még gyorsabban emelkedett, ezért viszonylagos gazdasági lemaradásuk fokozódott. Ugyanebben az időszakban a KKEU-i EU-tagországok mindegyikét a térség fejlettebb részéhez viszonyított, ugyancsak gyors méretnövekedés jellemezte, eközben azonban népességük csökkent a fejlettebb EU-tagországokhoz viszonyítva (többségük esetében nemcsak relatív, hanem abszolút csökkenésröl van szó), így az időszakban tapasztalt gyorsabb GDP-növekedésük ennél is gyorsabb reálgazdasági felzárkózással járt együtt. ${ }^{22}$

Azt, hogy az egy főre jutó GDP relatív változásával mért fejlettségi felzárkózáshoz mennyiben járult hozzá a számláló - a relatív méret -, illetve a népesség viszonylagos változása, magam is fontos, elemzést érdemlő kérdésnek tartom, amelyre azonban csak akkor lehet választ adni, ha megkülönböztetjük egymástól a fejlettségi és a gazdasági méretkonvergenciát, és külön vizsgáljuk a népességváltozás hatását. ${ }^{23}$

Ami a piaci árfolyamon való (nominális) összehasonlítást illeti, ezt a szerzők azzal támasztják alá, hogy szerintük ez mutatja, hogy a külföld szemében mennyit ér az, amit itthon megtermeltünk. ${ }^{24}$ Szerintem viszont ez a mérce alkalmatlan a fejlettségi szintek összehasonlítására és a felzárkózás mérésére, ráadásul azt is feltételezi, hogy a külföldet tartós pénzillúzió jellemzi. ${ }^{25}$

Először is, annak, amit Magyarországon megtermeltünk, a külföld szempontjából csak az a része érdekes piaci árfolyamon mérve, amit exportálunk (akár áruk, akár szolgáltatások - például idegenforgalom - formájában), a döntő résznek belföl-

${ }^{21}$ Az adatbázis tartalmáról és módszertanáról lásd Bolt és Zanden (2020) ismertetését.

${ }^{22}$ Ez az 1995 és 2019 közötti időszak egészét tekintve érvényes megállapítás, de a 2008 utáni periódusban a fejlettségi felzárkózás csekély „méretbeli” felzárkózással társult - erre visszatérek.

${ }^{23}$ A kérdéssel Krekó és Oblath (2018:38-42) is foglalkozott az 1995-2016 közötti időszak adatai alapján. Frissebb adatokra támaszkodva visszatérek a kérdésre.

${ }^{24}$ Fellegi (2021) ennél furcsább érvvel támasztotta alá az országok közötti nominális összehasonlítást: „,[a]z adatoknál a nominális, azaz tényleges számokat vesszük figyelembe, hisz ha vásárlóerőparitás alapján számolnánk, sokszor meglehetősen torznak tűnő adatokat kapunk, ami egyrészt annak köszönhető, hogy rendkívül nehéz az egyes országok árszínvonalát összehasonlítani (már csak az eltérő szerkezetű fogyasztás miatt is)". Ugyanez a nehézség az időbeli összehasonlítás esetében is fennáll, a GDP volumenváltozását mégsem folyó forintban, hanem az árszintváltozás hatását kiszürve mérjük.

${ }^{25}$ A pénzillúzió azt jelenti, hogy a nominális változásokat (szintkülönbségeket) reálváltozásoknak (reálkülönbségeknek) véljük, mert eltekintünk az árszintváltozás (árszintkülönbség) hatásától. A pénzillúzió példája, hogy a nominális béremelkedést, az infláció hatását figyelmen kívül hagyva, reálbéremelésnek hisszük. A pénzillúzióról lásd Vincze (2018), a „térbeli pénzillúzió” jelenségéről pedig Oblath (2014) írását. 
di szempontból van jelentősége, mégpedig forintban, nem pedig dollárban mérve. Másodszor, a nemzetközi színvonal-összehasonlítások nem arról szólnak, hogy a külföld szemében mennyit ér a hazai termelés, hanem arról, hogy a hazai termelés (illetve annak egy före jutó) mennyisége - országok között összehasonlítható árakon, vagyis PPP-n számítva - mennyivel különbözik más országokétól. Harmadszor, amint már szó volt róla, az a módszer, amellyel az Eurostat - a korábban említett ICP-módszertan szerint - a GDP-re vonatkozó PPP-t számítja, és amellyel összehasonlíthatóvá teszi az országok termelésének reálszintjét, a külkereskedelmet piaci árfolyamon veszi figyelembe, pontosan úgy, ahogyan azt a szerzők javasolják. ${ }^{26}$

De gondoljuk tovább a külföld szemével nézés logikáját. Ha a külföldet csakugyan a szerzők nézőpontja jellemezné, és csak a nominális összehasonlítások érdekelnék, akkor azt kellene gondolnunk, hogy a külföldiek kollektív pénzillúzió áldozatai. Nem az érdekelné őket, hogy saját pénzükért, átváltás után, egy másik országban az otthoninál nagyobb vagy kisebb méretü árukosár kapható-e, hanem az, hogy az otthonival azonos árukosár drágább vagy olcsóbb-e, és szemükben a drágább többet, az olcsóbb pedig kevesebbet érne. Ennek az elképzelésnek a furcsaságát a keretes írásban szereplő fiktív példa érzékelteti.

\section{Egy fiktív példa}

Tegyük fel, hogy egy adott évben két ország - az egyiket nevezzük Finnországnak, a másikat Svédországnak - pontosan ugyanazt az áru- és szolgáltatáskosarat állítja elö, méghozzá pontosan ugyanazon az euróban kifejezett áron (Finnországban az euró, Svédországban a korona a nemzeti valuta). A következő évben egyik országban sem változik a termelés mennyisége, Finnországban az árszint is változatlan, Svédországban viszont 10 százalékkal megugrik az euróban kifejezett árszint. Ez két módon (vagy a kettő kombinációjaként) következhet be: Svédországban megemelkedik a koronában mért árszint, de nem változik a nominális árfolyam, illetve úgy, hogy a korona felértékelődik az euróval szemben és nem változik az árszint. A példa feltételezi, hogy nem érvényesül az úgynevezett egységes ár elve, így az euróban kifejezett árszintkülönbség tartósan fennmaradhat.

Kérdés, hogy az euróban mért 10 százalékos drágulás után a külföld szemében többet ér-e a Finnországéval fizikailag továbbra is tökéletesen azonos svéd árukosár. A finnek szemében biztosan nem, amit azzal nyilvánítanak ki, hogy

${ }^{26}$ Lásd Eurostat \& OECD, 2012:42. 
nem vásárolnak Svédországban (miközben a svédek Finnországban igyekeznek bevásárolni). De ha mégis maradna olyan külföldi, akinek a szemében a svéd kosár a finnországinál 10 százalékkal többet ér, akkor a közgazdász dolga felvilágosítani, hogy térbeli pénzillúzió áldozata: a svéd kosár euróban kifejezett, nominális mérete megnőtt ugyan, de ugyanennyivel emelkedett az euróban mért árszintje is, így reálmérete mit sem változott. Ennek kimutatására szolgál a vásárlóerő-paritás.

Ugyancsak nominálisan, folyó dollárban mérve értelmezte a felzárkózást Berend T. Iván, amikor egy fontos cikkében (Berend, 2020a) illusztratív példán mutatta be, hogy azonos abszolút növekmény magasabb növekedési rátát jelent a fejletlen, mint a fejlett országban. Ennek az állításnak az érvényessége nem függ attól, hogy folyó áron vagy vásárlóerő-paritáson mérünk-e, de Simonovits (2020a) egy technikai pontosításban felhívta a figyelmet arra, hogy a szerző ,az egy főre jutó magyar és a német GDP-adatot vásárlóérték-paritás nélkül számolja, így 1:3 aránnyal számol a reálisabb 1:2 vagy alacsonyabb arány helyett". Berend (2020b) erre nem azt a kézenfekvő választ adta, hogy állításának lényegét nem befolyásolja, hogy nominális vagy reálértéken hasonlítunk össze, hanem a dollárban való mérés mellett érvelt. Amint írta, ,[...] az egy före jutó GDP-adatokat valóságos értéken, nem vásárlóérték-paritáson számoltam, nem tévedésből, hanem azért, mert ez fejezi ki, hogy az országok mennyi értéket termelnek, vagyis a valóságos szintkülönbséget. A vásárlóérték-paritás fontos abban az esetben, ha az életszintkülönbséget akarjuk összevetni, mivel az figyelembe veszi az árkülönbségeket is az országok között. Írásomban azonban nem ezt vizsgáltam" (kiemelések - O. G.).

Berend állítása az előbb hivatkozott szerzőkénél erősebb. Ő nem a külföld szemével néz, hanem megállapítja, hogy a valóságos értéket a nominális érték jelenti, a valóságos szintkülönbséget pedig a nominális szintkülönbség fejezi ki. A terminológián fölösleges vitatkozni, de érdemes emlékeztetni arra, hogy a valóságos az időbeli és keresztmetszeti összehasonlításokban általában a reál jelentésének felel meg, vagyis olyan mutatószámnak, amely kiszüri az árszintváltozásokat, illetve árszintkülönbségeket. Az, hogy a termelt értéket folyó áron és árfolyamon mért mennyiségnek tekinti, arra utal, hogy az értéket az értékindexszel (az ár- és volumenváltozás szorzatával) analóg módon értelmezi.

Az idézett gondolatmenet azonban nyitva hagy egy lényeges módszertani kérdést. Ha az életszínvonalak összehasonlítása szempontjából fontos szem előtt tartani az országok közötti árszintkülönbségeket, akkor ezeket miért lehet figyelmen kívül 
hagyni az egy före jutó termelési (fejlettségi) szintek összehasonlításakor? ${ }^{27} \mathrm{Ha}$ az életszintkülönbségeket reálértéken (PPP-n) indokolt mérni, akkor mi indokolhatja, hogy a fejlettségi szintkülönbségeket az árszintkülönbségek kiszürése nélkül, folyó áron mérjük? Ha e két fontos mutatót kétféle módon mérnék, azt kellene mondani, hogy Magyarország GDP/fövel mért fejlettségi szintje 2019-ben (euróban mérve) Ausztria egyharmadán állt, miközben a hazai életszínvonal (az egy före jutó egyéni fogyasztás PPP-jén mérve) az osztrák szint 57 százalékának felelt meg.

Ez éppen a fordítottja lenne annak a nem kevésbé alaptalan, de gyakran megfogalmazott állításnak, amely szerint a hazai relatív bérszint (s így az életszínvonal) jelentősen elmarad az ország fejlettségi szintjétől. Ezt úgy szokták alátámasztani, hogy a munkajövedelmet (életszínvonalat) folyó áron, a fejlettséget viszont PPP-n hasonlítják össze. ${ }^{28}$ Eszerint az euróban kifejezett egy före jutó háztartási fogyasztás az osztrák szintnek mindössze 30 százalékán állt volna 2019-ben, miközben a PPP-n mért GDP/fö Ausztria 57 százalékának felelt meg. Ha azonban mindkét tételt azonos módon, az árszintkülönbségek kiszűrésével mérjük, akkor azt találjuk, hogy 2019-ben a hazai reálfogyasztás és a reálfejlettség egyaránt Ausztria szintjének 57 százalékán állt. A két ország közötti részletesebb összehasonlításokra a következő szakaszban térek rá.

\section{Az Európai Unión belüli nominális, ár- és reálgazdasági felzárkózás 1995 és 2019 között: statisztikai összehasonlítások és ökonometriai elemzés}

A továbbiakban először két bilaterális példa, majd szélesebb európai összehasonlítások alapján tekintem át a nominális szintek és változások összetevőit. A kétoldalú példák azért hasznosak, mert az elvontnak látszó fogalmak - nominális, ár- és reálszintek, illetve változások - empirikus jelentését két ország egybevetése alapján könnyebb érzékelni, mint szélesebb összehasonlításban. Ezért az első lépésben Lengyelországot Magyarországhoz, majd Magyarországot Ausztriához viszonyítom, és ezek után térek rá az EU egészét - ezen belül a KKEU-i térséget - jellemző folyamatokra. felvetődik.

${ }^{27}$ Ez a kérdés természetesen Csillag és Mihályi (2020) előbb idézett érvelésével kapcsolatban is

${ }^{28}$ Az ilyen összehasonlításokon alapul a „bérlemaradás” tézise, amelynek problémáiról lásd Oblath, 2014a. 
A felzárkózást (illetve annak hiányát) a kontextustól függő mutatószámokkal számszerüsítem. ${ }^{29} \mathrm{~A}$ bilaterális összehasonlításoknál, valamint a KKEU-i térség és az EU27 átlagának egybevetésénél a relatív szintek időbeli alakulását és a viszonylagos növekedési ütemeket nézem. Az EU egészére vonatkozó áttekintésben viszont az úgynevezett szigma konvergenciát (a szintek relatív szórásának változását), az ökonometriai becsléseknél pedig az úgynevezett béta konvergenciát (a növekedési ütemek és a bázisidőszaki szintek közötti összefüggést) vizsgálom.

4.1. Példák a relatív nominális szintek és változások felbontásának jelentőségére

Lengyelország és Magyarország

A 3. ábra azt mutatja, hogy Lengyelországban hogyan alakult a Magyarországhoz viszonyított GDP-árszint, valamint az egy före jutó GDP-szint euróban, illetve PPP-n mérve 1995 és 2015 között.

3. ábra

\section{Lengyelország Magyarországhoz viszonyított egy fôre jutó GDP-je euróban} (NLCgdp), vásárlóerő-paritáson (VLCgdp) mérve és a GDP árszintje (PLgdp) 1995 és 2019 között

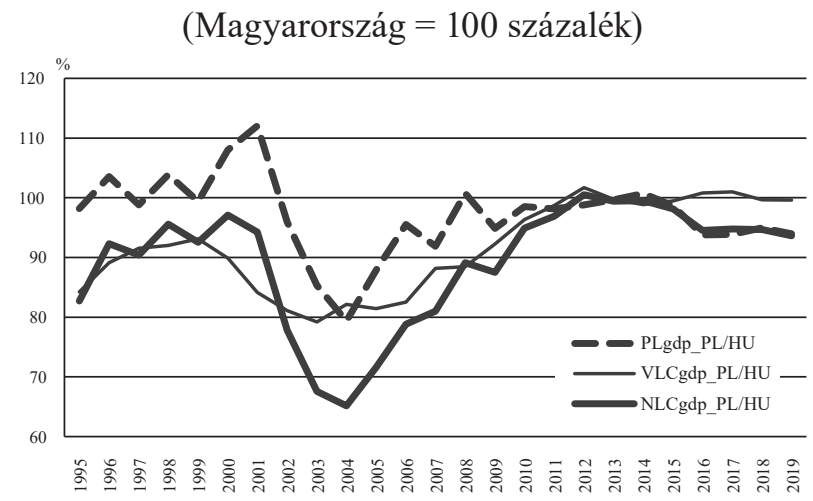

Forrás: Eurostat alapján saját számítások.

29 A konvergencia mérésének eltérő megközelítéseiről lásd Oblath (2013). 
A nominális felzárkózás időben változó összetevői: reálgazdasági és...

Az ábrán látható, hogy a 2000-es évek elején euróban mérve ${ }^{30}$ Lengyelország egy főre jutó nominális GDP-je Magyarországhoz viszonyítva jelentősen csökkent (lásd az ábrán a vastag fekete görbét). A zuhanás mértéke kifejezetten drámainak tünhet, hiszen 2001 és 2004 között 95-ről 65 százalékra esett Lengyelország relatív színvonala. Ha azonban szemügyre vesszük e rövid idő alatt bekövetkezett relatív nominális változás összetevőit, azt találjuk, hogy Lengyelország euróban mért relatív árszintjének jelentős csökkenése áll a jelenség hátterében: 110-ről 80 százalékra, közel 30 százalékkal süllyedt Lengyelország Magyarországhoz viszonyított árszintje (ekkora volt a zlotynak a forinttal szembeni reálleértékelödése - lásd a szaggatott vonalat). Az egy före jutó reálszintben alig történt elmozdulás (vékony fekete vonal).

Ennek ismeretében meglehetősen furcsa lenne azt mondani, hogy 2001 és 2004 között Lengyelország „,valóságos fejlettségi szintje” Magyarországhoz viszonyítva 30 százalékkal visszaesett (vagy azt állítani, hogy egy lakosra vetítve relatíve ennyivel kevesebb „értéket termelt”), viszont megállapíthatjuk, hogy a nominális szintek alakulása félrevezető a reálfelzárkózás megítélése szempontjából. Ezt a 2004 és 2012 közötti fejlemények is alátámasztják. Ebben az időszakban 65-ről 100 százalékra emelkedett Lengyelország relatív nominális szintje, de ez megint nem azt jelenti, hogy Lengyelország Magyarországhoz viszonyított valóságos fejlettségi szintje 35 százalékponttal (55 százalékkal) nőtt volna. E jelentős nominális növekedés abból eredt, hogy a relatív ár- és az egy fơre jutó relatív reálszint egyaránt nagyjából 80-ról 100 százalékra (25 százalékkal) emelkedett. Ezek a változások külön-külön és együttesen is érdekesek, de annak, hogy a kettő szorzataként a folyó áron mért relatív szint 55 százalékkal nőtt $\left(1,25^{*} 1,25 \approx 1,55\right)$, nincs közvetlenül értelmezhető közgazdasági jelentése.

Emellett az is fontos és érdekes, hogy - amint az a 3. ábrán ugyancsak jól látható - 2012 és 2014 között Lengyelország árszintje és termelésének egy före jutó reálszintje csaknem azonos volt Magyarországéval. Az viszont, hogy így az egy före jutó nominális szintek is azonosak voltak, önmagában nem tartalmaz közgazdasági információt. A nominális szintek megfelelése akár úgy is elóállhat, hogy az egyik ország reálszintje például 25 százalékkal magasabb, árszintje viszont 20 százalékkal alacsonyabb a másiknál $(1,25 * 0,8=1)$. A relatív ár- és az egy före jutó reálszint közötti reláció viszont fontos információ. ${ }^{31}$

${ }^{30}$ Emlékeztetőül: a keresztárfolyamok azonossága folytán közömbös, hogy zlotyban, forintban, dollárban vagy euróban mért folyó áras adatokat vetünk-e egybe, ha az országok mutatói azonos valutában vannak kifejezve.

${ }^{31}$ Ez a valuták alul-, illetve túlértékeltségére nézve és a valuta-félreértékeltség növekedési hatásait illetően tartalmazhat információt, lásd Krekó \& Oblath, 2020. 
Az előzőekben a tárgyalt fogalmak és összefüggések illusztrációjaként többször hivatkoztam Magyarország és Ausztria közötti összehasonlításokra, amelyekről az 1. táblázat nyújt rendezettebb áttekintést. A táblázat a hazai gazdaság Ausztriához viszonyított 1995. és 2019. évi pozíciójáról (1. és 2. oszlop, illetve 5. és 6. oszlop), valamint időközben bekövetkezett változásáról (3. és 4. oszlop) néhány kiemelt relatív makrogazdasági mutatószám alapján igyekszik képet adni. A relatív mutatók a következők: $a$ GDP nominális és reálmérete (1. és 3. sor); a GDP árszintje (2. sor); népesség (4. sor); a GDP/fö euróban és PPP-n (5. és 6. sor); a GDP/foglalkoztatott euróban és PPP-n (8. és 9. sor); az egyéni fogyasztás/fö euróban, PPP-n és a fogyasztás árszintje (14., 16. és 15 . sor). ${ }^{32}$

PPP-n mérve a GDP/fö a fejlettségi szintet, a GDP/foglalkoztatott a munkatermelékenységi szintet, az egyéni fogyasztás/fó pedig az életszínvonalat hivatott reprezentálni. Az, hogy a táblázatban e mutatók nominális (euróban kifejezett) relatív szintje és változása is szerepel, nem azt jelenti, hogy az így mért indikátoroknak közgazdasági jelentést tulajdonítok. A nominális arányokat (változásaikat) azért tüntettem fel, hogy látható legyen: mit kell közgazdaságilag értelmezhető ár- és reálösszetevőkre bontani, illetve mely - kétféle módon mérhető - ár- és reálváltozások eredője a nominális változás. (A nemzeti számlák relatív deflátoraival, illetve volumenindexeivel számított változások a 10-13. és a 17-18. sorban láthatók.) A nominális mutatók egyben a reálszintkülönbségek (-változások) felfúvódásának mértékét is érzékeltetik. Ehhez kapcsolódik két előzetes megjegyzés:

- Amíg a nominális relatív GDP/föt illetően elgondolkodhatunk azon, hogy a mutatónak lehet-e közgazdasági jelentése (mivel ebben az összefüggésben a GDP a jövedelmek és a termelés nominális összegét egyaránt jelentheti), addig a „,nominális" termelékenység és életszínvonal mutatóját illetően nincs min gondolkodni, mivel ez utóbbiak csak reálértéken (egy dolgozóra jutó termelési, illetve egy lakosra jutó fogyasztási volumenként, vagyis relatív reálszintként, illetve reálváltozásként) értelmezhetők. ${ }^{33}$

32 Az egyéni fogyasztás szintjét és változását az úgynevezett „,tényleges egyéni fogyasztással” (actual individual consumption) mérem, ami a háztartási fogyasztási kiadásoknak (vásárolt fogyasztás) és a természetbeni társadalmi juttatásoknak az összege. A fogyasztás árszintje (változása) is ennek a kategóriának felel meg.

33 Érdemes emlékeztetni arra, hogy a nominális szintek (változásuk) az ár- és reálszintek (változásának) a szorzata, az évi átlagos növekedési ütemek (4. oszlop) viszont jó közelítéssel additívak: a nominális változás éves üteme az ár- és a reálnövekedési ütem összege. 
A nominális felzárkózás időben változó összetevői: reálgazdasági és...

- Az utolsó két oszlopban Ausztria Magyarországhoz viszonyított mutatói szerepelnek (az első két oszlopban látható relatív szintek inverzei), amelyek az intuícióhoz közelebb álló módon érzékeltetik az euróban kifejezett szinteknek és változásaiknak az árszintkülönbségek (változásaik) miatti felfúvódását.

1. táblázat

\section{Magyarország Ausztriához viszonyított egyes nominális és reálmutatószámai} és azok változása 1995-2019 között

\begin{tabular}{|c|c|c|c|c|c|c|c|}
\hline & \multicolumn{4}{|c|}{ Magyarország/Ausztria } & \multirow{2}{*}{\multicolumn{2}{|c|}{$\begin{array}{c}\text { Memo: } \\
\text { Ausztria/Magyarország } \\
\text { Szintek }\end{array}$}} \\
\hline & & \multicolumn{2}{|c|}{ Szintek } & \multicolumn{2}{|c|}{ Változások } & & \\
\hline & & 1 & 2 & 3 & 4 & 5 & 6 \\
\hline & & 1995 & 2019 & $2019 / 1995$ & Évi átlag \% & 1995 & 2010 \\
\hline 1 & $\begin{array}{l}\text { GDP millió } \\
\text { euróban (nomi- } \\
\text { nális méret) }\end{array}$ & 0,19 & 0,36 & 1,87 & 2,6 & 5,2 & 2,8 \\
\hline 2 & $\begin{array}{l}\text { GDP relatív } \\
\text { árszint (PPS/E) }\end{array}$ & 0,38 & $\mathbf{0 , 5 7}$ & 1,49 & 1,7 & 2,6 & 1,8 \\
\hline $3=1 / 2$ & $\begin{array}{l}\text { GDP PPS-ben } \\
\text { (reálméret) }\end{array}$ & 0,50 & 0,63 & 1,26 & 0,9 & 2,0 & 1,6 \\
\hline 4 & Népesség & 1,30 & 1,10 & 0,85 & $-0,7$ & 0,8 & 0,9 \\
\hline $5=1 / 4$ & GDP/fö euróban & 0,15 & 0,33 & 2,21 & 3,3 & 6,7 & 3,1 \\
\hline $6=5 / 2$ & $\begin{array}{l}\text { GDP/fó PPS- } \\
\text { ben }\end{array}$ & 0,39 & $\mathbf{0 , 5 7}$ & 1,48 & 1,6 & 2,6 & 1,7 \\
\hline 7 & $\begin{array}{l}\text { Foglalkoztatot- } \\
\text { tak/népesség }\end{array}$ & 0,85 & 0,95 & 1,12 & 0,5 & 1,2 & 1,1 \\
\hline 8 & $\begin{array}{l}\text { GDP/foglalkoz- } \\
\text { tatott euróban }\end{array}$ & 0,18 & 0,34 & 1,97 & 2,8 & 5,7 & 2,9 \\
\hline $9=8 / 2$ & $\begin{array}{l}\text { GDP/foglalkoz- } \\
\text { tatott PPS-ben }\end{array}$ & 0,46 & 0,60 & 1,32 & 1,2 & 2,2 & 1,7 \\
\hline 10 & $\begin{array}{l}\text { GDP-árindex } \\
\text { euróban*/ }\end{array}$ & & & 1,57 & 1,9 & & \\
\hline $11=1 / 10$ & $\begin{array}{l}\text { GDP-volumen- } \\
\text { index*/ }\end{array}$ & & & 1,19 & 0,7 & & \\
\hline $12=5 / 10$ & $\begin{array}{l}\text { GDP/fö volu- } \\
\text { menindex*/ }\end{array}$ & & & 1,41 & 1,4 & & \\
\hline $13=8 / 10$ & $\begin{array}{l}\text { GDP/foglalkoz- } \\
\text { tatott volumen- } \\
\text { index*/ }\end{array}$ & & & 1,25 & 1,0 & & \\
\hline
\end{tabular}




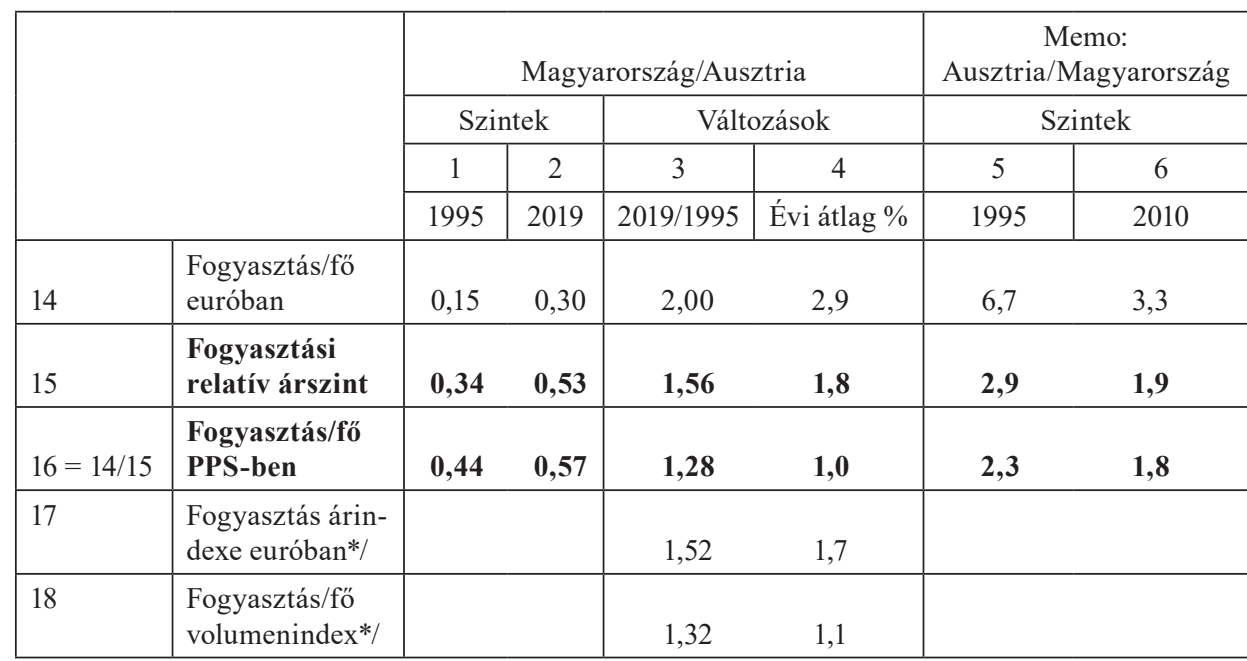

Jelölések: PPS: purchasing power standard (az Eurostat által számított vásárlóerő-paritás); E: valutaárfolyam (hazai valuta/euró).

*/ A nemzeti számlákból számított adatok.

Forrás: Eurostat alapján saját számítások.

Az összehasonlítások fontosabb eredményei a következőkben összegezhetők:

1. A nominális (euróban kifejezett) szintkülönbségeket a reálszintkülönbségekhez viszonyítva brutálisan felnagyítják az árszintkülönbségek. 1995-ben, illetve 2019-ben az osztrák GDP/fö euróban kifejezett értéke 6,7, illetve 3,1-szerese volt a hazainak (5. sor 5., illetve 6. oszlop). PPP-n mérve (reálértéken) azonban ennél jóval kisebb, 2,6, illetve 1,7-szeres volt a különbség (6. sor) és nagyjából ugyanilyen arányú volt az árszintkülönbség (2. sor).

2. Az euróban mért hazai relatív növekedés mértékét a relatív reálnövekedéshez képest jelentősen felnagyítja a reálfelzárkózást kisérö árszintfelzárkózás. A vizsgált időszakban euróban mérve Ausztriához viszonyítva 2,2-szer nőtt gyorsabban Magyarországon az egy före jutó GDP (5. sor 3. oszlop), de ennél lényegesen kisebb, mintegy 50 százalékos volt a reálnövekedési többlet (6. sor 3. oszlop). Vagyis az Ausztriához viszonyított, évi átlagban 3,3 százalékos nominális többletnövekedésnek (5. sor 4. oszlop) nagyjából a fele tulajdonítható a reálfelzárkózásnak (6. sor 4. oszlop), a másik fele az euróban mért gyorsabb árszintemelkedéshez köthető (2. sor 4. oszlop).

3. Az egy fóre jutó GDP lényegesen gyorsabb hazai reálgazdasági felzárkózást jelez (évi 1,6 százalék), mint a GDP viszonylagos reálnövekedése (évi 0,9 száza- 
A nominális felzárkózás időben változó összetevői: reálgazdasági és...

lék), amely utóbbiétól alig maradt el a relatív népességcsökkenés hozzájárulása (évi 0,7 százalék) a reálfelzárkózáshoz.

4. Viszonylagos munkatermelékenységi szintünk az időszak elején számottevően magasabb volt a fejlettségénél (46 versus 39 százalék), a rés azonban jelentősen szükült (60 versus 57 százalék). Termelékenységi felzárkózásunk számottevően elmaradt az egy lakosra jutó termelésétől (évi 1,2 versus 1,6 százalék).

5. Az egy főre jutó reálfogyasztással mért relatív hazai életszínvonal - figyelembe véve, hogy a fogyasztás árszintje mindvégig alacsonyabb volt a GDP-jénél - az időszak elején inkább a termelékenységgel volt összhangban (44 százalék), az időszak végén azonban a háromféle mutató nagyjából szinkronban volt. A viszonylagos életszínvonal emelkedése (évi 1 százalék) jóval elmaradt az egy főre jutó termelésétől, de nem állt távol a termelékenység növekedésétől.

6. A PPP alapján mért relatív reálszintváltozások a termelést és a termelékenységet tekintve gyorsabb hazai felzárkózást jeleznek, mint a relatív volumenindexek (lásd a 11-13. sort; az eltérés az időszak egészére nézve mintegy 7 százalékpont). Ennek tükörképe, hogy a GDP-deflátorral mért árszintfelzárkózás gyorsabb volt, mint amit a PPP-vel mért árszintváltozás jelez. A fogyasztást tekintve viszont a különbség elhanyagolható, ami azt jelzi, hogy az összetételhatást illetően jelentős különbségek lehetnek az egyes felhasználási tételek között.

Az összehasonlítás tanulságai közül kettőt emelek ki. Az egyik az, hogy a gazdasági felzárkózást nemcsak az egy före jutó GDP-vel, hanem többféle makrogazdasági mutatószám alapján és alternatív statisztikai forrásokra támaszkodva érdemes mérni. A másik, és nem kevésbé fontos: a felzárkózást sem nominális mutatókkal, sem a gazdaságok relatív méretének változásával nem tanácsos mérni.

A felzárkózási folyamat megítélése szempontjából természetesen az időbeli profil is fontos: a bázis- és a tárgyidőszak között tapasztalt változásnak mekkora része köthető egyes részperiódusokhoz? Ez volt Csillag és Mihályi (2020) fő kérdése, amelyre azt a választ adták, hogy az EU KKEU-i tagországainak Ausztriához történt felzárkózása 2008 után elakadt. A következő szakaszban - a szerzőkétől eltérő fogalmakat és módszereket alkalmazva - megkérdőjelezem ezt a következtetést. Az EU KKEU-i térségére, majd az EU egészére vonatkozó elemzés előkészítéseként mutatom be a 4.1. és 4.2. ábrát: mindkettő Magyarország Ausztriához történt ár- és reálgazdasági felzárkózásának és nominális közeledésének időbeli alakulásáról ad képet. A 4.1. ábra két grafikonja a szintek alakulását, a 4.2. ábra az 1995-höz viszonyított változásokat mutatja. 
Az ábra bal oldalán fekete vonal jelöli a hazai GDP Ausztriához viszonyított nominális (euróban mért) nagyságát, reprodukálva Csillag és Mihályi cikkének 1. ábráját (azzal a különbséggel, hogy itt az idősor 1995-től indul és a 2019. évvel végződik). Jól látszik, hogy a GDP nominális mérete 2008-ig csaknem folyamatosan közeledett Ausztriáéhoz, azt követően azonban nőtt a távolság, és a 2012-től tapasztalt újabb közeledés eredményeként 2019-re csak megközelíteni sikerült a 2008. évi relatív méretet. Nyomatékosan hangsúlyozva, hogy a relatív reálméret és a relatív árszint között nincs közvetlen közgazdasági összefüggés, az ábra bal oldalán látható, hogy 2008-ig a gyors relatív árszintemelkedésnek (a forint reálfelértékelődésének - szaggatott vonal) a reálméret változásánál (szürke vonal) nagyobb szerepe volt a nominális méretkülönbség csökkenésében; 2008 után pedig döntően a relatív árszintcsökkenéshez köthető a nominális méretkülönbség növekedése.

\section{1. ábra}

\section{GDP-árszint, gazdasági méret és fejlettség - Magyarország Ausztriához viszonyított mutatói, 1995-2019}

Relatív árszint, nominális és reálméret (GDP)

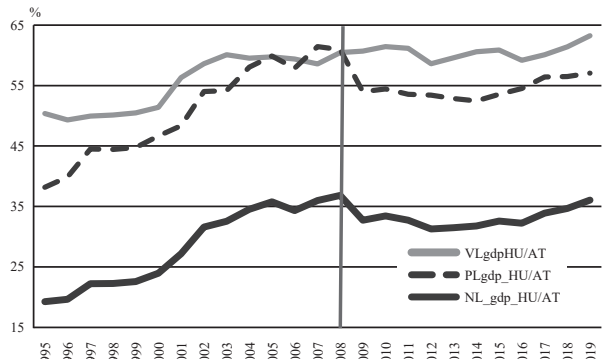

Relatív árszint, nominális és reálfejlettség (GDP/fö)

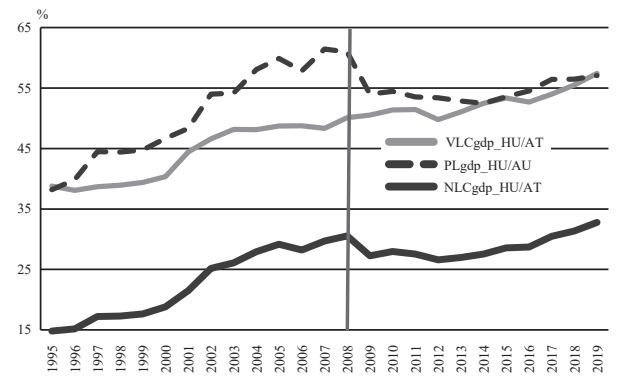

Jelölések: PLgdp, VLgdp és NLgdp: a GDP árszintje, reál- (PPP-n mért) és nominális (euróban kifejezett) mérete; VLCgdp és NLCgdp: az egy före jutó GDP reál és nominális nagysága. Valamennyi indikátor Magyarország Ausztriához viszonyított szintjét mutatja.

Forrás: Eurostat alapján saját számítások.

A méretkülönbség, illetve annak változása azonban nem jelent fejlettségi különbséget, illetve gazdasági felzárkózást. Az utóbbiakról az ábra jobb oldali grafikonja ad képet, amelyen az egy forre jutó GDP relatív nominális és reálszintje látható, valamint a relatív árszint (amelynek értéke az ábra mindkét oldalán természetesen megegyezik). Egyértelmü, hogy 1995 és 2008 között sokkal jelentősebb volt az ár- 
szintközeledés, mint a reálgazdasági felzárkózás (mindkét mutató 40 százalék körül volt 1995-ben, de miközben árszintünk Ausztria 60 százalékára, reálfejlettségi szintünk csak 50 százalékára emelkedett). 2008 és 2019 között megváltoztak a folyamatok, és árszintünk - hullámzásokkal - az időszak végére 57 százalékra csökkent, reálfejlettségünk viszont ugyanerre a szintre nőtt. Bár az egy före jutó nominális GDP csekély változást jelez (31 versus 33 százalék), ez egyértelmủen a relatív árszint csökkenéséhez köthető. Ezért megalapozatlan azt állítani, hogy 2008 után elakadt az Ausztriához viszonyított reálfelzárkózásunk.

Nem ennek az írásnak a tárgya, hogy milyen sajátos tényezőknek tulajdonítható a 2010-es évtized viszonylag gyors hazai gazdasági növekedése (a jelentős EUtranszferek szerepét mindenképpen meg kell említeni, erről lásd például Oblath \& Palócz, 2020), de arra még visszatérek, hogy az egy före jutó GDP-vel mért reálfelzárkózáshoz technikailag mennyiben járult hozzá a relatív népességváltozás.

4.2. ábra

\section{Az Ausztriához viszonyított egy före jutó hazai GDP és árszint változása alternatív mutatók alapján}

$(1995=1)$

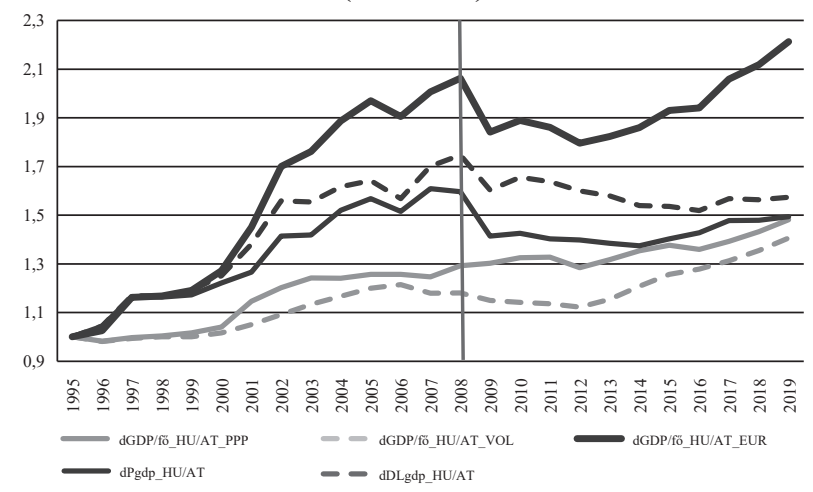

Jelölések: dPgdp, illetve dDLgdp: a PPP alapján, illetve a deflátor alapján mért relatív GDP-árszint változása.

Forrás: Lásd a 4.1. ábrát.

A 4.1. ábra a PPP-n mért relatív ár- és reálszinteket mutatja, amint azonban korábban szó volt róla, a relatív változások nemcsak a PPP-n mért szintek alakulása, hanem a relatív ár- és volumenindexek alapján is mérhetők. A 4.2. ábra a kétféle megközelítés szerinti relatív változásokról 1995. évi bázison ad képet. 
A vastag fekete vonal a GDP/fó Ausztriához viszonyított nominális változását, a feketék az árszintnek, a szürkék pedig a GDP/fö reálértékének relatív változását jelölik. A telt vonalak a PPP szerinti, a szaggatottak pedig a relatív ár- és volumenindexekkel mért fejleményeket mutatják. Mindkét felbontás szerint 2008-ig az árszintfelzárkózás a reálfelzárkózásnál lényegesen nagyobb mértékben járult hozzá a nominális változásokhoz. Az is látszik, hogy ebben az időszakban a PPP-n mért reálfelzárkózás gyorsabb volt, mint amit a relatív volumenindex jelez (ennek tükörképe, hogy a PPP-n mért árfelzárkózás lassúbb volt, mint amit a relatív deflátor mutat).

A 2008 és 2019 közötti időszak egészét tekintve két szempontból is megváltoztak az irányzatok (az időszakon belüli hullámzás összetevőitől eltekintek). Egyrészt mindkét felbontás szerint a relatív árszintváltozás visszafogta, a reálváltozás viszont elősegítette a nominális növekedést. Másrészt megváltoztak a PPP-n, illetve a volumenindexszel mért változások közötti relációk: a volumenindex - különösen 2012től - gyorsabb reálfelzárkózást jelez, mint a PPP-n mért mutató (ennek megfelelően a deflátor kisebb árszintcsökkenésre utal, mint a PPP-n mért árszintváltozás).

2. táblázat

\section{Magyarország egyes makrogazdasági mutatóinak változása Ausztriához viszonyítva 1995 és 2008, valamint 2009 és 2019 között}

(Évi átlagos növekedési ütemek, százalék)

\begin{tabular}{|l|l|c|c|}
\hline & & $1995-2008$ & $2009-2019$ \\
\hline 1 & GDP nominális változás (euróban) & 5,0 & $-0,2$ \\
\hline 2 & Népességváltozás & $-0,6$ & $-0,8$ \\
\hline $3=(1-2)$ & GDP/fö nominális változás (euróban) & 5,6 & 0,6 \\
\hline 4.1 & Árszintváltozás a GDP-PPP alapján & 3,6 & $-0,6$ \\
\hline 4.2 & Árszintváltozás a GDP-deflátor alapján & 4,3 & $-0,9$ \\
\hline $5.1=1-4.1$ & GDP reálváltozás PPP alapján & 1,4 & 0,4 \\
\hline $5.2=1-4.2$ & GDP reálváltozás volumenindex alapján & 0,7 & 0,7 \\
\hline $6.1=5.1-2$ & GDP/fó reálváltozás PPP alapján & 2,0 & 1,2 \\
\hline $6.2=5.2-2$ & GDP/fó reálváltozás volumenindex alapján & 1,3 & 1,5 \\
\hline $7=(6.1-6.2)$ & $\begin{array}{l}\text { A PPP-n és a volumenindexszel mért változás különb- } \\
\text { sége }=\text { a deflátorral és a PPP-n mért árszintváltozás } \\
=(4.2-4.1)\end{array}$ & & \\
\hline
\end{tabular}

Megjegyzés: a növekedési ütemek additívak, de a kerekítések miatt nem pontosan adják ki az összegeket, illetve különbségeket.

Forrás: Eurostat alapján saját számítások. 
A nominális felzárkózás időben változó összetevői: reálgazdasági és...

A 2. táblázat a 2008-ig tartó, valamint a 2009 és 2019 közötti időszak közötti változásokat veti egybe az Ausztriához viszonyított évi átlagos növekedési ütemek alapján.

Az 1. sorban közölt relatív nominális GDP-növekedési adatok alátámasztani látszanak azt az állítást, hogy 2008 után elakadt a hazai gazdaság felzárkózása. Évi 5 százalékos növekedési többlet után évi -0,2 százalék csakugyan durva váltást jelez, akárcsak az, hogy a GDP/fö relatív nominális növekedési üteme 5,6-ról 0,6 százalékra csökkent (3. sor). Amint azonban láttuk, a reálfelzárkózás időszakok közötti összehasonlításához a nominális változásból ki kell szűrni a relatív árszintváltozás hatását (lásd a 4.1 és a 4.2 sort).

A reálfelzárkózás szempontjából releváns összehasonlítások a 6.1 és a 6.2 sorban láthatók: a második időszakban PPP-n mérve évi 2-ről 1,2 százalékra csökkent, a relatív volumenindexek alapján pedig évi 1,3-ról 1,5 százalékra emelkedett a hazai egy före jutó GDP Ausztriához viszonyított reálnövekedési többlete. Az első mutató szerint 2008 és 2019 között lassult, de egyáltalán nem állt meg, a második szerint pedig kissé gyorsult a hazai reálfelzárkózás.

Ezen a ponton érdemes megismételni: a gazdasági felzárkózás és a relatív gazdasági méretnövekedés fogalmának megkülönböztetése nélkül nem lehet válaszolni arra az okkal felmerülő technikai kérdésre, hogy a felzárkózáshoz az egyes időszakokban milyen arányban járult hozzá a relatív méret-, illetve népességváltozás (5.1 és 5.2, illetve 2. sor). A PPP alapján mérve 30-ról 66 százalékra (2/0,6 versus 1,2/0,8), a volumenindexek alapján mintegy 45-ről 55 százalékra (1,3/0,6 versus 1,5/0,8) emelkedett a hazai népesség Ausztriáéhoz viszonyított csökkenésének hozzájárulása az egy före jutó GDP reálnövekedési többletéhez. Ez az irányzat arra hívja fel a figyelmet, hogy a felzárkózási folyamat hosszabb távú fenntarthatósága megítéléséhez a Csillag és Mihályi által kiemelt összetevő, a relatív méretváltozás hozzájárulását is indokolt figyelemmel kísérni.

Végül amint a 7. sorban szereplő mutatók jelzik: az első periódusban a PPP-n mért reálfelzárkózás lényegesen gyorsabb, a második időszakban viszont lassúbb volt a relatív volumenindexek által jelzettnél. A korábban javasolt fogalmat használva, az összetételhatás az első időszakban Magyarország Ausztriához viszonyított PPP-n mért reálfelzárkózását pozitív irányban, a másodikban viszont negatív előjellel befolyásolta (a relatív volumenindex jelzésével összehasonlítva).

Amint említettem és az online Függelékben bemutatom, az EU-tagországok körében a jelentős összetételhatásnak általában viszonylag jó magyarázó tényezője a külkereskedelmi cserearányok változása, ez a magyarázat azonban Magyarország 
esetében egyáltalán nem müködik. Mindenesetre a relatív volumenindex által jelzett irányzatok sokkal könnyebben illeszthetők a hazai makrogazdasági folyamatokról alkotott összkép egészébe (lásd a 4.2. ábrán a szaggatott szürke vonalat), mint a PPP-n mért mutató által jelzettek (telt szürke vonal).

4.2. A nominális, az ár-és a reálszintek közeledése az Európai Unióban 1995 és 2019 között - két részperiódusban

A továbbiakban először az EU KKEU-i tagországai felzárkózásának egyes metszeteit tekintem át, majd az EU-n belüli reálgazdasági és árkonvergenciára vonatkozó grafikus illusztrációk és becslési eredmények alapján mutatom be a felzárkózási folyamat 1995 és 2008 közötti, valamint az azt követő, 2019-ig tartó időszakának jellegzetességeit.

\subsubsection{Szintkülönbségek és dinamikák: az EU közép-és kelet-európai térsége relatív} pozíciójának alakulása

Kiindulópontként az EU KKEU-i tagországai EU átlagához történt felzárkózásának jellemzőit vizsgálom, arra is választ keresve, hogy mennyiben általánosak, illetve specifikusak a Magyarország és Ausztria közötti összehasonlítások eredményei.

A 3. táblázat arról ad áttekintést, hogy hol állt az EU11 KKEU-i tagországainak egy före jutó GDP-szintje euróban és PPP-n mérve, továbbá árszintje az EU27 átlagához viszonyítva 1995-ben, 2008-ban és 2019-ben. A táblázatban Ausztria megfelelő adatai is szerepelnek, ami segít tisztázni, hogy az Ausztriához való viszonyítás mennyiben reprezentálja az EU átlagához mért közeledést. Az EU11, a KKEU-i tagországok és az EU felzárkózó tagországai megjelöléseket a továbbiakban azonos értelemben használom.

A viszonyítási pont reprezentativitásához kapcsolódik az a választás, hogy a felzárkózó EU-tagországok fejleményeit nem az EU15-höz (az alapító és a korábban csatlakozott, fejlettebb tagországokhoz), hanem a mai EU-átlaghoz viszonyítom, amelyet az összehasonlítandó felzárkózó országok adatai csekély mértékben ugyan, de maguk is befolyásolnak. E választás legfontosabb oka, hogy az EU15 átlagos mutatóira jelentős hatást gyakorolnak az Egyesült Királyság adatai, amelyek a PPP-n számított reálváltozásnak a volumenindexszel mért GDP-növekedéstől való számot- 
tevő elmaradását jelzik, ez pedig torzíthatja az összehasonlításokat. ${ }^{34}$ A 3. táblázat első sorából azonban az is kitünik, hogy az Ausztriához való viszonyítás sem problémamentes: az első periódusban az ország fejlettségi és árszintje egyaránt csökkent az EU-átlaghoz viszonyítva.

3. táblázat

\section{Az EU27 átlagához viszonyított egy fơre jutó GDP euróban és vásárlóerő- paritáson mérve, valamint a GDP árszintje 11 KKEU-i EU-tagországban és Ausztriában 1995-ben, 2008-ban és 2019-ben}

$(\mathrm{EU} 27=100)$

\begin{tabular}{|l|r|r|r|r|r|r|rr|r|}
\hline & \multicolumn{3}{|c|}{ GDP/fó_EUR } & \multicolumn{3}{c|}{ GDP/fó_PPP } & \multicolumn{3}{c|}{ GDP árszint } \\
\cline { 2 - 10 } & 1995 & 2008 & 2019 & 1995 & 2008 & 2019 & 1995 & 2008 & 2019 \\
\hline Ausztria & 156 & 140 & 144 & 133 & 127 & 127 & 117 & 110 & 113 \\
Bulgária & 12 & 19 & 28 & 44 & 43 & 53 & 27 & 45 & 53 \\
Csehország & 30 & 61 & 66 & 77 & 85 & 92 & 38 & 72 & 72 \\
Észtország & 14 & 49 & 68 & 36 & 70 & 84 & 38 & 70 & 81 \\
Horvátország & 25 & 44 & 43 & 45 & 64 & 65 & 56 & 69 & 66 \\
Lengyelország & 19 & 38 & 44 & 43 & 56 & 73 & 44 & 68 & 61 \\
Lettország & 11 & 44 & 51 & 31 & 60 & 69 & 36 & 74 & 74 \\
Litvánia & 9 & 40 & 56 & 33 & 64 & 82 & 28 & 64 & 68 \\
Magyarország & 23 & 43 & 47 & 52 & 64 & 73 & 45 & 67 & 65 \\
Románia & 8 & 28 & 37 & 31 & 52 & 69 & 28 & 55 & 53 \\
Szlovákia & 19 & 48 & 56 & 49 & 73 & $70(74)$ & 39 & 67 & $79(75)$ \\
Szlovénia & 55 & 74 & 74 & 77 & 91 & 88 & 72 & 82 & 84 \\
\hline EU11/EU27 & 21 & 45 & 52 & 47 & 66 & 75 & 41 & 67 & 68 \\
EU11/Ausztria & 13 & 32 & 36 & 35 & 52 & 59 & 35 & 60 & 60 \\
\hline
\end{tabular}

Megjegyzés: Az Eurostat a tanulmány adatbázisának összeállítását követően publikálta a 2019-re vonatkozó revideált PPP-adatokat, amelyek általában nem, illetve legfeljebb 1 százalékponttal különböznek a korábban közölt adatoktól. Egyedül Szlovákia relatív ár- és reálszintjében történt jelentős revízió, ezért zárójelben jelzem a revíziót megelőzően közölt adatokat, amelyeket, amint már jeleztem, a revideáltaknál sokkal hihetöbbeknek tartok.

Forrás: Eurostat (2020) és saját számítás

34 Például Magyarország esetében az 1995 és 2019 közötti időszak egészében a PPP-n mért relatív GDP-növekedés 8 százalékkal volt gyorsabb, mint amit a relatív volumenindex jelez - ha az EU15 a viszonyítási pont. Ez az arány 3 százalékra csökken, ha az EU27-hez viszonyítunk, s így elhanyagolhatóvá válik a 2019. évi folyó PPP-n és a 1995. évi konstans PPP-n mért szint közötti különbség. 
Az EU11 átlaga (alsó két sor) egyszerü számtani átlagot jelent, mivel a súlyozás jelentéktelenné tenné a kisebb országokra vonatkozó, figyelmet érdemlő megfigyelések jelentőségét. E tekintetben a következő szakaszban közölt konvergenciaelemzés logikáját követem.

A 3. táblázatban közölt mutatókat nem országonként tekintem át, hanem az EU11 átlagára összpontosítok (utolsó előtti sor), de kitérek az átlagtól való jelentősebb eltérésekre, és az Ausztriával való összehasonlításra (utolsó sor) is felhívom a figyelmet.

A vizsgált időszak egészében a KKEU-i térséget jelentős reálgazdasági és árszintfelzárkózás jellemezte: 1995 és 2019 között a PPP-n mért reálfejlettségi szint az EU27 egészéhez viszonyítva 47-ről 75 százalékra, az árszint 41-ről 68 százalékra emelkedett. Az is látható azonban, hogy amíg a 2008-ig tartó idöszakban az EU átlagához történt reál- és árfelzárkózás egyaránt számottevő volt, addig a második periódusban a reálfelzárkózás folytatódott (66-ról 75 százalékra), az árszintfelzárkózás viszont elakadt (67 versus 68 százalék).

Egyes országok fejleményei láthatóan kilógnak az összképből. Bulgáriában és két balti országban (Lettország kivételével) a második periódusban nemcsak a reálfelzárkózás, hanem az árfelzárkózás is folytatódott. Szlovénia és Szlovákia esetében viszont annak ellenére folytatódott az árfelzárkózás, hogy a reálfelzárkózás elakadt. Ezekben az országokban rögzített árfolyamrendszer müködött, illetve egyesek az euróövezet részévé váltak, ami magyarázatot adhat az összképtől való eltérésre. (Szlovákia esete, amint már szó volt róla, sajátos: rendkívül kevéssé hihetők az ország PPP-n mért árszintadatai által jelzett időbeli változások.)

Az ellentétes irányú eltérésekre viszont a rugalmas árfolyamrendszer kínálhat magyarázatot: Lengyelországot (és - enyhébb mértékben - Magyarországot) az első időszakban a reálfelzárkózásnál nagyobb mértékü árszintfelzárkózás jellemezte, ez a reláció azonban a második időszakban megfordult (valutáik 2008 után leértékelődtek), és a folytatódó reálfelzárkózást relatív árszintcsökkenés kísérte. Így a relatív árszint a relatív reálszintnél jóval alacsonyabbra süllyedt 2019-re, ami az érintett országok valutáinak 2008. évi túlértékeltségét és 2019. évi alulértékeltségét valószínüsíti. ${ }^{35}$

Azt is érdemes megfigyelni, hogy Ausztria reálfejlettségi és árszintje az EU átlagához viszonyítva egyaránt csökkent az első periódusban, a második időszakban viszont árszintje kissé emelkedett, miközben a GDP/fő reálszintje stagnált. Így a két időszak közötti összehasonlítását tekintve az Ausztriához történő viszonyítás rossz

35 Ez az értelmezés Krekó és Oblath (2020) tanulmányának megközelítésére támaszkodik. 
reprezentánsa az EU átlagához mért változásoknak; ezt a dinamikák egybevetése is alátámasztja (4. táblázat).

4. táblázat

Évi átlagos növekedési ütemkülönbségek az EU11, valamint az EU27, illetve Ausztria között 1995-től 2019-ig, két részperiódusban a következő mutatókban: nominális és reálméret, árszint, népesség, nominális és reálGDP/fó

(Százalékpont)

\begin{tabular}{|c|c|c|c|c|c|c|c|c|c|}
\hline \multirow[b]{3}{*}{$\begin{array}{l}\text { EU11/ } \\
\text { EU27 }\end{array}$} & 2019/95 & $2008 / 9$ & $2019 / 2008$ & 2019/95 & 2008/95 & 2019/2008 & 2019/95 & 2008/95 & $2019 / 2008$ \\
\hline & \multicolumn{3}{|c|}{ GDP euróban [1] } & \multicolumn{3}{|c|}{ Népesség [2] } & \multicolumn{3}{|c|}{ GDP/fö euróban [3 = 1-2] } \\
\hline & 3,8 & 6,1 & 1,0 & $-0,6$ & $-0,7$ & $-0,5$ & 4,4 & 6,7 & 1,5 \\
\hline \multirow{2}{*}{\begin{tabular}{|l} 
EU11/ \\
AT
\end{tabular}} & 3.8 & 68 & 0.3 & -0.9 & -08 & $-0,9$ & 4.7 & 76 & 1.2 \\
\hline & \multicolumn{3}{|c|}{ Árszint (PPP/E) [4] } & \multicolumn{3}{|c|}{ GDP PPP alapján [5=1-4] } & \multicolumn{3}{|c|}{ GDP/fö PPP alapján [6 = 5-2] } \\
\hline $\begin{array}{l}\text { EU11/ } \\
\text { EU27 }\end{array}$ & 2,3 & 4,0 & 0,3 & 1,5 & 2,1 & 0,7 & 2,1 & 2,8 & 1,3 \\
\hline \multirow[t]{2}{*}{\begin{tabular}{|l} 
EU11/ \\
AT
\end{tabular}} & 2,4 & 4,4 & 0,0 & 1,4 & 2,4 & 0,3 & 2,3 & 3,1 & 1,2 \\
\hline & \multicolumn{3}{|c|}{$\begin{array}{l}\text { GDP-deflátor } \\
\text { [7] }\end{array}$} & \multicolumn{3}{|c|}{$\begin{array}{c}\text { GDP volumenindex alapján } \\
{[8=1-7]}\end{array}$} & \multicolumn{3}{|c|}{$\begin{array}{c}\text { GDP/fö vol. index alapján } \\
{[9=8-2]}\end{array}$} \\
\hline $\begin{array}{l}\text { EU11/ } \\
\text { EU27 }\end{array}$ & 2,3 & 3,9 & 0,3 & 1,5 & 2,2 & 0,7 & 2,1 & 2,8 & 1,2 \\
\hline $\begin{array}{l}\text { EU11/ } \\
\text { AT }\end{array}$ & 2,5 & 4,8 & $-0,3$ & 1,4 & 2,0 & 0,6 & 2,2 & 2,8 & 1,6 \\
\hline & \multicolumn{3}{|c|}{$\begin{array}{c}\text { Összetételhatás } \\
{[10=(7-4)=(5-8)]}\end{array}$} & & & & & & \\
\hline $\begin{array}{l}\text { EU11/ } \\
\text { EU27 }\end{array}$ & 0,0 & $-0,1$ & 0,0 & & & & & & \\
\hline $\begin{array}{l}\text { EU11/ } \\
\text { AT }\end{array}$ & 0,1 & 0,4 & $-0,3$ & & & & & & \\
\hline
\end{tabular}

Megjegyzés: A kerekítések miatt a mutatók esetenként nem pontosan adják ki a szögletes zárójelekben jelzett összefüggéseket.

Forrás: Eurostat alapján saját számítások.

A 4. táblázat az EU11-térség átlagának kétféle módon mért relatív reál-GDP/fö növekedésének éves ütemét bontja statisztikai összetevőkre. A felső blokk a nomi- 
nális GDP/fö relatív növekedésének komponenseit, a relatív méret- és népességváltozást mutatja. A középső blokk a PPP alapján, az alsó blokk pedig a relatív GDPdeflátor alapján bontja a nominális változásokat ár- és reálösszetevőre. Az egyes országok időszaki átlagaira vonatkozó adatok a Melléklet M1.-M4. táblázataiban szerepelnek, a mutatók országonkénti időbeli alakulásáról pedig az M1.-M4. ábrák tájékoztatnak.

Mivel a 4. táblázatban közölt mutatók mindegyike az EU átlagához, illetve Ausztriához viszonyított növekedési ütemkülönbséget jelöl, az adatok diszkussziójában egyszerủen növekedésről, illetve változásról beszélek, ez azonban minden esetben relativ növekedést, illetve változást jelent. A két időszak fejleményeit a következő szempontokból vetem egybe: (1) a felzárkózó térség gazdaságainak nominális növekedéséhez mennyiben járult hozzá a GDP ár-, illetve reálszintjének változása, továbbá számít-e, hogy PPP-n vagy a GDP-deflátorral mérjük az árszintváltozást; (2) a reálgazdasági felzárkózáshoz (a GDP/fö növekedéséhez) mennyiben járult hozzá a reálméret, illetve a népességváltozás. Elöször az EU átlagához viszonyított fejleményeket tekintem át, majd (3) bemutatom, hogy mely tekintetben módosítja a képet, ha Ausztriához viszonyítunk.

1. Az első időszak jelentős nominális méretnövekedését egyértelmüen az árszintemelkedés dominálta, ahogyan a második időszak számottevő nominális lassulása is elsősorban az árszintemelkedés ütemének csökkenéséhez köthető. A GDP reálméret-növekedését tekintve lényegesen kisebb volt a lassulás. Az EU átlagához viszonyítva nem mutatkozik számottevő eltérés a PPP alapján, illetve a deflátorral mért árszintváltozás (és egyben a PPP alapján, illetve a volumenindexszel mért reálváltozás) között, vagyis ebben az összehasonlításban az összetételhatás elhanyagolható volt.

2. A felzárkózás itt használt mutatója azzal társult, hogy KKEU-i országok népessége csökkent (emlékeztetőül: a táblázatban szereplő számok relatív népességcsökkenést jeleznek). Az első időszakban egyértelműen a reálméret növekedése volt a meghatározó, a másodikban viszont a GDP lelassult reálnövekedésével csaknem egyenrangúvá vált a népességváltozás technikai hozzájárulása a reálfelzárkózáshoz.

3. Az időszak egészének átlagos mutatóit tekintve, az Ausztriával, illetve az EU átlagával való egybevetés eredményei alig különböznek egymástól. Az érdemi különbségek a két időszak összehasonlításához kapcsolódnak.

Először is -Csillag és Mihályi megállapításával összhangban - Ausztriához képest a második időszakban minimálissá vált a GDP nominális növekedése, de a periódu- 
A nominális felzárkózás időben változó összetevői: reálgazdasági és...

sok közötti növekedési ütemváltás is sokkal erőteljesebb, mint az EU átlagához viszonyítva (6,5 versus 5,1 százalékpont). Másodszor, ha a GDP reálnövekedését nézzük, Ausztriához viszonyítva nagyon is számít, hogy PPP-n vagy a relatív volumenindexszel mérünk: az előbbi esetben a második periódust minimális növekedés és drámai lassulás jellemzi, az utóbbi esetben lényegesen kisebb a két periódus közötti kontraszt. Harmadszor, mivel az Ausztriához viszonyított népességcsökkenés nagyobb arányú, mint az EU27-hez viszonyítva (sőt, az előbbi összehasonlításban kissé gyorsult, az utóbbiban lassult a népesség zsugorodása), a második időszakban az egy före jutó GDP Ausztriához mért reálnövekedéséhez nagyobb részben a relatív népességcsökkenés járult hozzá, függetlenül attól, hogy PPP-n vagy volumenindexszel mérünk-e.

Mindent egybevetve, amint a 4. táblázat utolsó két oszlopából kitűnik, akárhogyan mérünk, illetve akár az EU27-hez, akár Ausztriához viszonyítunk, az egy före jutó GDP-t tekintve az EU11 országcsoport átlagosan mind az első, mind pedig a második periódusban gyorsabban növekedett a viszonyítás bázisánál, vagyis a térség egészét reálgazdasági felzárkózás jellemezte. A reálfelzárkózás azonban az első időszakban egyértelműen gyorsabb volt, mint a másodikban. A lassulás mértéke erősen függ attól, hogy az EU átlagához vagy Ausztriához viszonyítunk, továbbá - az utóbbi esetben - attól is, hogy PPP-n vagy a relatív volumenindexekkel mérjük-e az EU11 növekedési többletét. Ebből természetesen nem következik, hogy az Ausztriával való összehasonlítás bármiféle értelemben hibás lenne, az viszont igen, hogy ennek eredményét annak ismeretében indokolt értelmezni, hogy egyes részidőszakokban Ausztria mutatói mennyiben különböztek az EU átlagáétól. (Az EU11 átlagának, illetve Ausztriának az EU27-hez viszonyított egyes fejleményeiről az online Melléklet M1., illetve M2. ábrája 1995. évi bázison ad képet.)

Az átlagok mögötti heterogenitás részleteiről ugyancsak az online Mellékletben szereplő táblázatok és ábrák tájékoztatnak. ${ }^{36}$ Itt két ábra érzékelteti az országok közötti különbségeket a két vizsgált periódusban. Az ábrák az egyes KKEU-i országoknak az EU átlagához viszonyított egy före jutó nominális GDP-jének évi átlagos növekedési ütemét $\left(n l c_{g d p}\right)$ a következö összefüggés alapján bontják tényezökre:

$$
n l_{g d p}=p l_{g d p}+\underbrace{q v l_{g d p}-p o p}_{v l c_{-} g d p}+\underbrace{\left(r d_{\text {gdp }}-p l_{\text {gdp }}\right)}_{\text {"összetételhatás" }}
$$

${ }^{36}$ Az online Mellékletben szereplő M1.-M5. táblázat a 11 KKEU-i országra és Ausztriára nézve közli azokat a mutatókat, amelyek átlagos értékei a 4. táblázatban szerepelnek. Az M1. ábra az EU11 átlagának az EU27 átlagához viszonyított mutatóinak, az M2. ábra Ausztria hasonlóan mért mutatóinak alakulását mutatja 1995. évi bázison, 1995 és 2019 között. Az M3.-M6. ábrák az egyes EU11-tagországokra vonatkozó, a főszöveghez kapcsolódó kiegészítő információkat tartalmaznak. 
A kis betük az EU átlagához mért évi átlagos növekedési ütemkülönbségeket jelölik, de az egyszerübb szóhasználat végett csak változásról lesz szó. Az azonosság azt mutatja, hogy a GDP/fó nominális (euróban mért) változása PPP-n mért ár- és reálváltozásból tevődik össze $\left(n l c_{g d p}=p l_{g d p}+v l c_{g d p}\right)$. A PPP-n mért reálváltozás pedig két részre bontható: a volumenindexszel mért GDP/fó változására $\left[q v l c_{g d p}=\left(q v l_{g d p}-\right.\right.$ $p o p)$ ], valamint a deflátorral és a PPP-vel mért árszintváltozás különbségére ( $r d g d p$ - plgdp), amelyre összetételhatásként hivatkozom. (Ez értelemszerűen megegyezik a PPP-vel és a volumenindexszel mért reálváltozás különbségével.)

Az 5.1. ábra az egy före jutó GDP euróban mért változását bontja a PPP-n mért ár- és reálváltozásra, az 5.2. ábra pedig az utóbbi tételt bontja tovább három komponensre: a volumenindexszel mért GDP-méretváltozására, a népességváltozásra és az összetételhatásra az 1996 és 2008, illetve a 2009 és 2019 közötti időszakban.

5.1. ábra

Hozzájárulások GDP/fó EU27 átlagához viszonyított, euróban mért évi átlagos növekedéshez (NLCgdp): a PPP-n mért egy fôre jutó GDP relatív reálváltozása (VLCgdp) és a relatív árszint változása (PLgdp) a KKEU-i EUtagországokban, két periódusban

(Százalékpont)
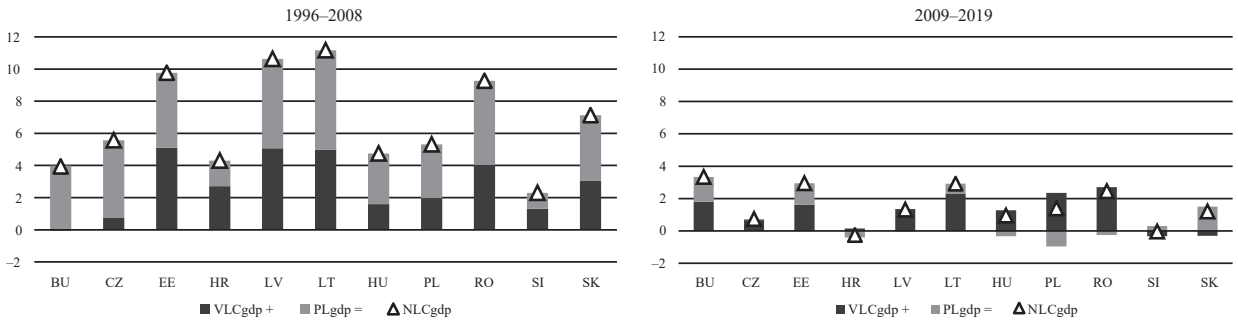

Forrás: Eurostat alapján saját számítások.

Az ábra bal oldalán látható, hogy az EU27-hez viszonyítva az 1996 és 2008 közötti időszakban a KKEU-i országokban - a korábban Jugoszlávia részét képező Horvátország és Szlovénia kivételével ${ }^{37}$ - a PPP-n mért árszintemelkedés tette ki a nominális GDP/fö emelkedésének a nagyobb részét. A jobb oldali grafikon pedig azt mutatja,

${ }^{37}$ Az eltérés azzal magyarázható, hogy a két exjugoszláv ország ár- és bérszintje - a munkás-önigazgatás örökségeként - az 1990-es évek elején jóval magasabb volt a többi KKEU-i országénál (erröl lásd Kónya \& al., 2020). 
hogy a 2009 és 2019 között az EU27-hez viszonyított nominális növekedési többlet az előző időszakhoz képest mindenütt jelentősen csökkent (Horvátországban és Szlovéniában lényegében meg is szűnt), ami elsősorban ahhoz köthető, hogy a relatív árszintemelkedés számottevően lelassult, illetve négy országban előjelet is váltott.

Az 5.2. ábra a fenti ábra fekete oszloppal jelzett, PPP-n mért GDP/fő relatív változását bontja három összetevő: a GDP relatív volumenindex, a népesség relatív változása, valamint az összetétel-változás hatására.

5.2. ábra

Hozzájárulások GDP/fö EU27 átlagához viszonyított, PPP-n mért évi átlagos növekedéshez (VLCgdp): a volumenindexszel mért GDP relatív növekedése (QVLgdp), a relatív népességváltozás (inverze: -PoP) és az összetétel-változás (DFgdp-PLgdp) szerepe két időszakban

(Százalékpontban)
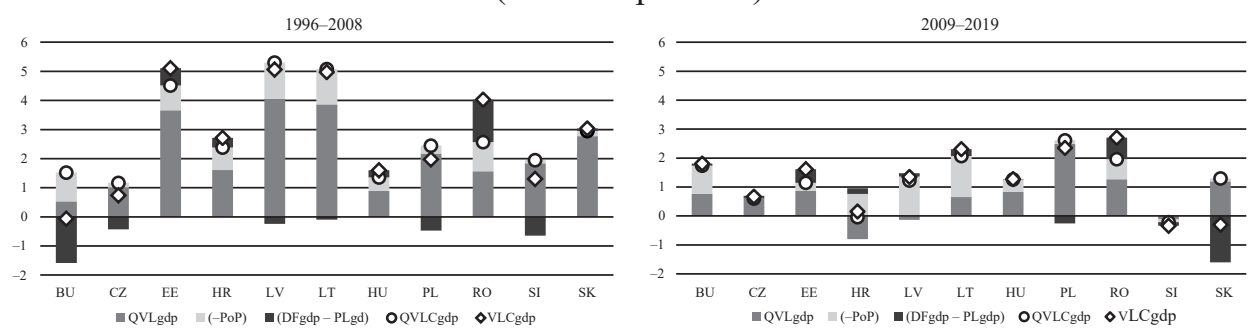

Megjegyzés: Az összetevők közötti relációkról lásd a fenti formulát.

Forrás: Lásd az 5.1. ábrát.

Az ábra két oldalának összehasonlításából kitünik, hogy a volumenindexszel mért relatív GDP-növekedés a második időszakban általában lelassult, sőt Horvátországban és Szlovéniában el is akadt. Az is látható, hogy mindkét időszakban és csaknem valamennyi országban (kivétel Csehország, Szlovénia és Szlovákia) a GDP/ fö relatív növekedéséhez technikailag a relatív népességcsökkenés is hozzájárult (szürke oszlop). Ami pedig az összetételhatás (fekete oszlop) elöjelét és mértékét illeti, mindkét időszakban számottevőek az országok közötti eltérések. Ez a hatás Észtország, Horvátország és Románia esetében konzisztensen pozitív (a PPP-n mért reálváltozás nagyobb a relatív volumenindex által jelzettnél), Lengyelországot és Szlovéniát tekintve viszont konzisztensen negatív.

Szlovákia már tárgyalt tapasztalatai azonban kirívóak. Amíg az első időszakban az összetételhatás enyhén pozitív volt, a második periódusban olyan mértékben vált 
negatívvá, hogy lényegében lenullázta, sőt negatívba fordította a relatív volumenindexszel mért pozitív változást. A korábban mondottakat megismételve: ez a kevéssé plauzibilis eredmény arra figyelmeztet, hogy ha az összetételhatás számottevő, nagyon óvatosan kell kezelni a PPP-n mért mutatók időbeli összehasonlításainak jelzéseit.

\subsubsection{Reálgazdasági és árszint-konvergencia az Európai Unióban: illusztráció és} becslési eredmények

Ebben a szakaszban a KKEU-i országok felzárkózására vonatkozó áttekintést az Európai Unió egészén belüli konvergencia kétféle metszetének elemzésével kívánom kiegészíteni, illetve alátámasztani. ${ }^{38}$ Külön vizsgálom a nominális közeledés két összetevője, az árszint- és a reálgazdasági felzárkózás alakulását, és mindkettőt kétféle módon, a PPP-n, illetve a relatív deflátorral (volumenindexszel) mért változásként számszerüsítem. Először az úgynevezett szigma konvergencia időbeli alakulását mutatom be, majd az úgynevezett béta konvergenciát vizsgálom 25 EUtagországra, ${ }^{39}$ az 1995 és 2019 közötti időszakra nézve, két részperiódusban. Reálgazdasági felzárkózáson továbbra is az egy före jutó GDP-szintek reálértéken mért közeledését értem, s ettől megkülönböztetem a reálméret-felzárkózást, amely a GDP relatív változásának hozzájárulása a GDP/fö relatív változásához. ${ }^{40}$

\section{Szigma konvergencia}

Akkor beszélünk szigma konvergenciáról, ha a keresztmetszeti szintek szóródása időben csökken. Ezt a megközelítést tükrözi a 6. ábra, amelynek felső része a következő három mutató relatív szórásának alakulásáról ad képet: az EU27-hez viszonyított GDP-árszint, a reál-GDP/fö, valamint a reálméret - amely kiszüri a népességváltozás technikai hatását. A bal oldalon a folyó $P P P-n$, jobb oldalon pedig az 1995. évi konstans PPP-n mért mutatók évenkénti relatív szórása látható a 1995 és 2019 közötti időszakban. A folyó és konstans PPP-n mért mutatók értéke a refe-

38 Az EU-n belüli reálgazdasági és árszintfelzárkózás gazdag irodalmának néhány fontos, illetve friss írására a bevezetőben hívtam fel a figyelmet.

39 Luxemburg, Írország és Málta nem szerepel a mintában. Luxemburg extrém GDP/fő adatai, Írország a 2015 utáni extrém (és félrevezető) növekedési mutatói, Málta pedig a hiányos idősorok miatt maradt ki a mintából.

40 A ,reálméret” változását jelző mutató a PPP-n mért bázisidőszaki (1995. évi) relatív GDP/fő és a GDP relatív reálváltozásának a szorzata, így a bázisévben a „reálméret” és a reálfejlettségi szint azonos, a tárgyévben pedig a relatív népességváltozás hatásától „megtisztítva” jelzi a GDP/fő relatív reálszintjét. Ez csupán illusztratív, technikai mutató, mivel nincs tekintettel magának a népességváltozásnak a GDP változására gyakorolt hatására. 
renciaévben (1995-ben) azonos, de a további években a konstans PPP-n kifejezett mutatók értékét a nemzeti számlákból származó relatív deflátorok, illetve volumenindexek alakulása határozzák meg. ${ }^{41}$ Az így mért szigma konvergenciát azért mutatom be, mert ez konzisztens a továbbiakban tárgyalt béta konvergenciának azzal a megközelítésével, amely a kezdeti - PPP-n mért - relatív szintek függvényében vizsgálja a nemzeti számlák alapján számított relatív növekedési ütemeket.

6. ábra

Szigma konvergencia az EU 25 tagországa között: a GDP-árszintek, a fejlettségi szintek és a reálméretek relatív szórásának alakulása folyó PPP-n

(bal oldal) és 1995. évi konstans PPP-n (jobb oldal), továbbá a nominális szintek és méretek relatív szórása (alsó grafikon) 1995 és 2019 között
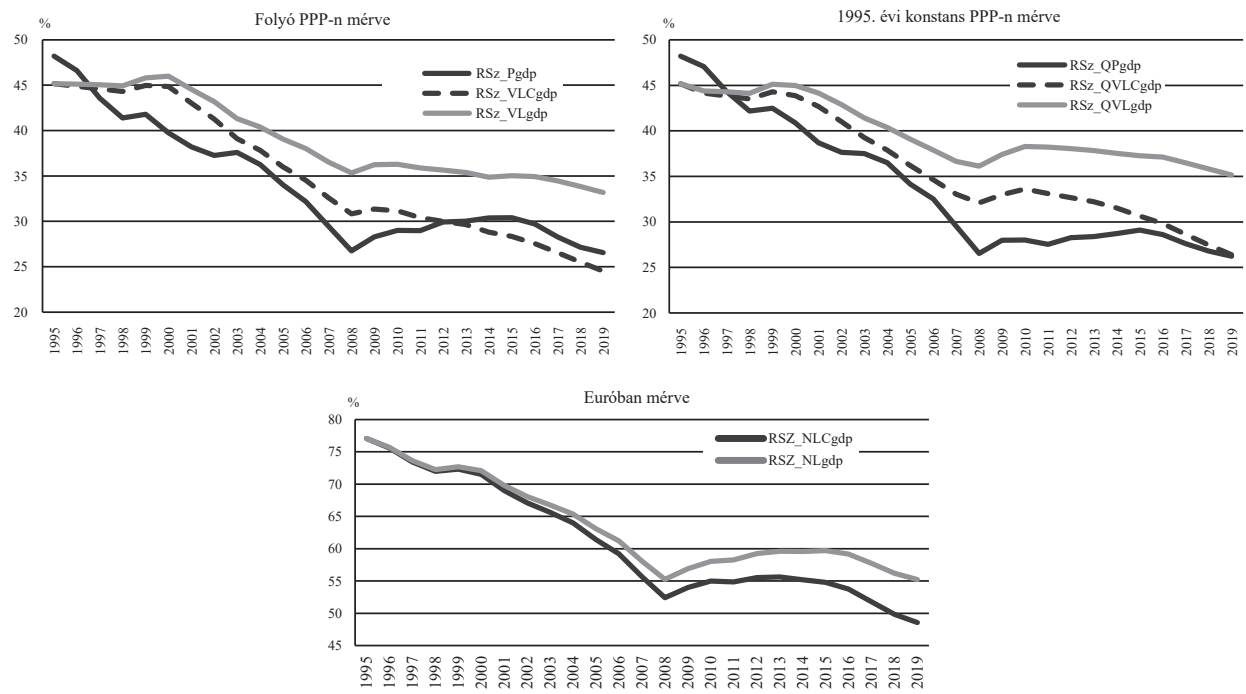

Megjegyzés: Az egyes évekhez tartozó adatpontok egyes mutatóknak az EU27 átlagához viszonyított szintjeinek relatív szórását jelzik. Jelölések: RSZ: relatív szórás. Folyó PPP-n mért mutatók: Pgdp, VLCgdp és VLgdp: a GDP árszintje, a GDP/fö szintje és a népességváltozás hatását kiszürő (a méretváltozást mutató) szintje. QPgdp, QVLCgdp, QVLgdp: az előbbi három mutató 1995. évi konstans PPP-n mérve. NLCgdp és NLgdp: GDP/fö szintje és GDP-méret euróban.

Forrás: Eurostat alapján saját számítások.

Az ábra alsó grafikonja - kiegészítő információként, nem pedig közgazdasági elemzés céljából - a nominális (euróban kifejezett) GDP/fö és gazdasági méret relatív szórásának időbeli alakulását is bemutatja.

${ }^{41}$ A konstans PPP-n mért mutatók meghatározásáról lásd a „Relatív szintek és változások” című keretes írás 4. pontját. 
Az ábra felső részének két oldala hasonló irányzatokat jelez 2008-ig, utána kissé különböznek a folyó és a konstans PPP-n mért fejlemények, most azonban azokra a markáns irányzatokra hívom fel a figyelmet, amelyekben nincs különbség a két megközelítés között (az eltérésekre még visszatérek). Az első és legfontosabb: 1995 és 2008 között lényegesen gyorsabb volt az árszintek közeledése, mint a GDP/fóvel mért fejlettségi szinteké, amely utóbbinál is lassúbb volt a reálméretek konvergenciája. A második: a 2008. év valamennyi mutató szerint egyfajta szakaszhatárt jelent: törés következett be az 1995-töl (árszintközeledés), illetve 2000-től tartó folyamatokban (reál-, illetve méretközeledés). A harmadik: 2008 után a reálgazdasági konvergencia átmeneti elakadás után és a korábbinál lassabban ugyan, de folytatódott. Ezzel szemben az árszintek alakulását növekvő divergencia jellemezte, ami csak 2016 után kezdett mérséklődni. A második időszakban a reálméret-közeledés is elakadt.

Az ábra alsó grafikonja az ár- és volumenfolyamatok eredőjét, az euróban mért nominális konvergencia alakulását érzékelteti. Látható, hogy mind a GDP/fö, mind pedig a GDP (a nominális méret) alapján gyors volt a szintek közeledése 2008-ig, de mindkét mutató azt jelzi, hogy ezt követően megfordultak az irányzatok. Ez is amellett szól, hogy a következő egyszerü ökonometriai elemzésben az 1995 és 2019 közötti időszakon belül 2008-at indokolt töréspontnak tekinteni.

Béta konvergencia

Akkor beszélhetünk béta konvergenciáról, ha szignifikáns negatív összefüggés mutatható ki egyfelől a bázis- és a tárgyév között tapasztalt növekedési ütemek, másfelől a bázisidőszaki szintek között. A következőkben azt vizsgálom, hogy ebben az értelemben az EU25-térségben mennyiben érvényesült reálgazdasági, illetve árszint-konvergencia a 1995-től 2019-ig tartó időszakban (ezen belül az 1995 és 2008, valamint a 2009 és 2019 közötti periódusokban). Kitérek arra, hogy egymással összehasonlítva hogyan alakult a reálgazdasági és az árfelzárkózás sebessége, és érintem a reálméret-, illetve népességváltozás hatását is. Az úgynevezett abszolút béta konvergencia meglétét tesztelem, ami azt jelenti, hogy az EU átlagához viszonyított növekedési ütemeket csak a kezdeti relatív szintek függvényének tekintem, és nem kontrollálok számos további fontos kezdeti különbségre (például humán tőke, eladósodottság, intézményi minőség stb.). A becslések keresztmetszeti egyenletekre, a béta konvergencia megléte, illetve mértéke megállapításának legegyszerübb módszerére támaszkodnak. 
A nominális felzárkózás időben változó összetevői: reálgazdasági és...

A konvergencia reáloldalát kétféle mutatóval, a reálgazdasági (reálfejlettségi) és reálméret-konvergenciával, valamint két statisztikai értelmezés szerint (PPP-n, illetve relatív volumenindexszel) mérem:

$$
d Y i=\alpha_{0}+\alpha_{1} \ln Y(\text { ppp })_{t 0}+\varepsilon
$$

Mind a függő, mind a független változó az EU27 átlagához viszonyított indikátor. $d Y i$ négyféle mutatót jelöl: évi átlagos növekedési ütemet a GDP/fö alapján (a) PPP-n, (b) volumenindexszel mérve; a GDP alapján (c) PPP-n, (d) volumenindexszel mérve. $Y(\text { (pp })_{t 0}$ : az egy före jutó GDP PPP-n mért szintje a bázisidőszakban (1995ben, illetve 2008-ban).

Amint az eddigiekből kiderülhetett, a nominális konvergencia fogalmát csupán a további elemzések kiindulópontjának tartom, de tartamától függetlenül ez is mérhető. Ehhez csak az kell, hogy az [1] egyenlet bal oldalára az euróban mért kezdeti relatív fejlettségi szintet, a jobb oldalra pedig az euróban mért relatív növekedési ütemet illesszük be.

Az árszint-konvergenciát két módon vizsgálom: az egyik specifikációban csak a kezdeti árszint, a másikban a GDP/fő növekedési üteme is magyarázó tényezője az árszintek változásának, és itt is különbséget teszek a PPP-n mért, illetve a relatív GDP-deflátorral számított árszintváltozás között:

$$
d P i=\gamma_{0}+\gamma_{1} \ln P_{t 0}+\gamma_{2} d Y i+\varepsilon
$$

A változók ez esetben is az EU27 átlagához viszonyítva értendők. $d P i$ az évi átlagos GDP-árszintváltozást jelöli, kétféle értelmezés alapján: (a) a PPP-n mért relatív árszintváltozás, (b) relatív GDP-deflátor; Pt0 a PPP-n mért relatív árszint a bázisidőszakban (1995-ben, illetve 2008-ban). dYi: az egy före jutó GDP évi átlagos növekedési üteme kétféle értelmezés alapján: (a) a PPP-n mért relatív reálváltozás, (b) relatív volumenindex.

Az [1], illetve [2] egyenleten alapuló, 25 EU-tagországra vonatkozó OLSbecslések eredményeit a 5., illetve 6. táblázat tartalmazza. A táblázatokban a kezdeti szintek együtthatóiból számítható konvergenciaütemek és az úgynevezett felezési idők is szerepelnek, amelyek megkönnyítik a becslési eredmények összehasonlítását. A konvergencia sebessége (béta) azt jelzi, hogy a vizsgált periódusban évente mekkora ütemben zsugorodott az országok kezdeti relatív szintjei között egyes mutatók tekintetében tapasztalt rés, vagyis negatív növekedési ütemet jelent. A felezési idő pedig azt érzékelteti, hogy - valamely időszakban tapasztalt konvergencia ütemének változatlanságát feltételezve - hány évig tartana a felzárkó- 
záshoz vezető út felének elérése. ${ }^{42}$ A 5., illetve 6. táblázat a felzárkózás reál-, illetve ároldalára vonatkozó eredményeket tartalmazza, amelyeknek a lényege a következőkben összegezhető (a diszkusszióban nem a táblázatok sorrendje, hanem egyes témák szerint haladok).

5. táblázat

Becslési eredmények: a reálgazdasági és reálméret-konvergencia, továbbá a relatív népességváltozás és a bázisidőszaki fejlettségi szint összefüggése az

EU25-ben 1995 és 2019 között és két részperiódusban

\begin{tabular}{|c|c|c|c|c|c|}
\hline & 1 & 2 & 3 & 4 & 5 \\
\hline & $d G D P / f o \ldots p p p p$ & $d Q \_G D P / f^{\prime \prime}$ & $d G D P \_p p p$ & $d Q_{-} G D P$ & dPop \\
\hline \multirow{3}{*}{$\ln \left(G D P / f o \_\right.$o5_ppp $)$} & \multicolumn{5}{|c|}{ 1996-2019 } \\
\hline & $-0,0257 * * *$ & $-0,0232 * * *$ & $-0,0166^{* * *}$ & $-0,0142 * * *$ & $0,0089 * * *$ \\
\hline & $(0,0024)$ & $(0,0022)$ & $(0,0026)$ & $(0,0025)$ & $(0,0012)$ \\
\hline korrR $R^{2}$ & 0,831 & 0,82 & 0,626 & 0,574 & 0,678 \\
\hline Béta & $4 \%$ & $3,4 \%$ & $2,1 \%$ & $1,7 \%$ & - \\
\hline \multirow[t]{2}{*}{ Felezési idő } & 17,3 & 20,4 & 32,7 & 40 & - \\
\hline & \multicolumn{5}{|c|}{$1996-2008$} \\
\hline \multirow[t]{2}{*}{$\ln \left(G D P / f_{0} \_95 \_p p p\right)$} & $-0,0315^{* * *}$ & $-0,0289 * * *$ & $-0,0225 * * *$ & $-0,0200 * * *$ & $0,0087 * * *$ \\
\hline & $(0,0036)$ & $(0,0033)$ & $(0,0040)$ & $(0,0034)$ & $(0,0015)$ \\
\hline korr $R^{2}$ & 0,755 & 0,761 & 0,561 & 0,586 & 0,587 \\
\hline Béta & $4,1 \%$ & $3,6 \%$ & $2,7 \%$ & $2,3 \%$ & - \\
\hline \multirow[t]{2}{*}{ Felezési idő } & 17 & 19 & 26 & 30 & - \\
\hline & \multicolumn{5}{|c|}{ 2009-2019 } \\
\hline \multirow[t]{2}{*}{$\ln \left(G D P / f o \_08 \_p p p\right)$} & $-0,0296 * * *$ & $-0,0260 * * *$ & $-0,0153^{* *}$ & $-0,0117 *$ & $0,0141 * * *$ \\
\hline & $(0,0059)$ & $(0,0052)$ & $(0,0065)$ & $(0,0066)$ & $(0,0022)$ \\
\hline korr $R^{2}$ & 0,499 & 0,501 & 0,161 & 0,101 & 0,6219 \\
\hline Béta & $3,6 \%$ & $3,1 \%$ & $1,7 \%$ & $1,3 \%$ & - \\
\hline Felezési idő & 19,4 & 22,6 & 40,4 & 55,3 & - \\
\hline
\end{tabular}

Magyarázat és jelölések: valamennyi változó az EU27 átlagához viszonyítva értendő. Függő változók (oszlopok): az egy före jutó GDP évi átlagos változása PPP-n és relatív volumenindexekkel mérve ( $d G D P / f o ́ p p p$ és $d Q \_G D P / f o ̈:$ 1. és 2. oszlop), illetve a GDP évi átlagos változása PPP-n és relatív volumenindexekkel mérve ( $d G D P \_p p p$ és $d Q_{-} G D P$ : 3. és 4. oszlop). Magyarázó változó (GDP/ fö_ppp): az egy före jutó GDP szintje. 1995-ben, illetve 2008-ban. Zárójelben: standard hiba; ***: $\mathrm{p}<0,01 ; * * \mathrm{p}<0,05 ; * \mathrm{p}<0,1$

Forrás: Eurostat alapján saját számítások.

${ }^{42}$ A konvergencia sebessége $(\beta)$ a fejlettségi rés zsugorodásának ütemét jelenti, amely az [1] egyenlet $\alpha_{1}$ együtthatójából a következő formulával számítható ki: $\beta=-\ln \left(1+\mathrm{T} \cdot \alpha_{1}\right) / T$, ahol $T$ a vizsgált időszak években mért hosszát jelöli. A felezési idő: $\ln (2) / \beta$. A részletekről lásd például Barro \& Sala-i-Martin, 2004:37. 
1. A GDP/fö alapján mért reálfelzárkózás kétféle értelmezés szerint a két idöszakban. A 5. táblázat 1. és 2. oszlopában közölt eredmények azt jelzik, hogy a vizsgált időszakban igen gyors, 3,4-4 százalékos volt a felzárkózás üteme, ami a 2008 előtti 3,6-4,1 százalékról 3,1-3,6 százalékra lassult a második időszakban. Mindkét periódusban a PPP-n mért felzárkózás gyorsabb volt a megbízhatóbbnak tekinthető volumenindex alapján mértnél. Az Európán belüli fejlettségi szintek béta konvergenciájának lassulása tehát egyértelmüen kimutatható, szó sincs azonban a folyamat elakadásáról.

6. táblázat

Becslési eredmények: az árszintfelzárkózás alakulása az EU25-ben 1995 és 2019 között és két részperiódusban a GDP relatív árszintje (PL) és deflátora (DF) alapján

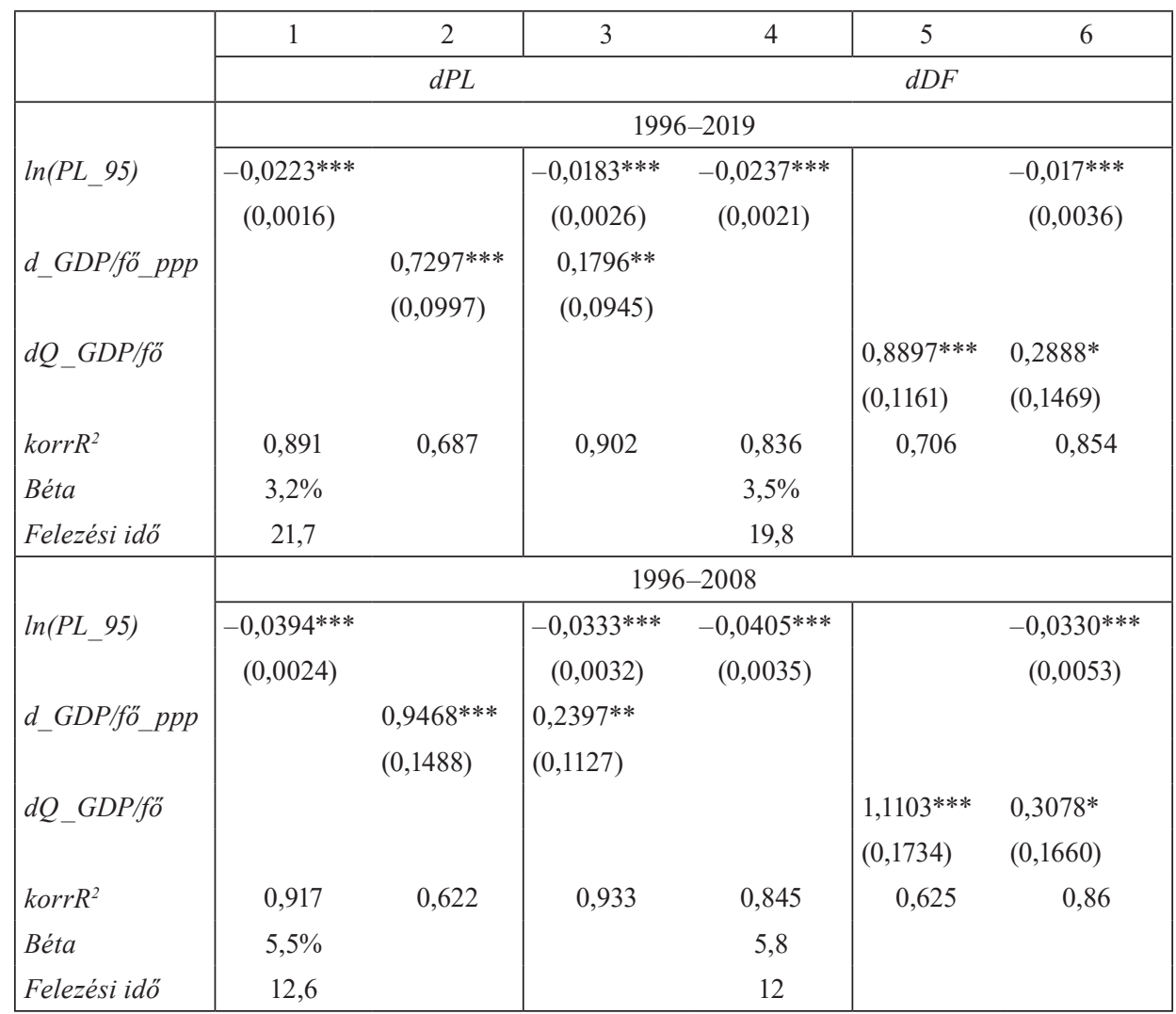




\begin{tabular}{|c|c|c|c|c|c|c|}
\hline & 1 & 2 & 3 & 4 & 5 & 6 \\
\hline & \multicolumn{3}{|c|}{$d P L$} & \multicolumn{3}{|c|}{$d D F$} \\
\hline \multirow{3}{*}{$\ln \left(P L \_08\right)$} & \multicolumn{6}{|c|}{ 2009-2019 } \\
\hline & $-0,0044$ & & $-0,0037$ & $-0,0071$ & & $-0,0024$ \\
\hline & $(0,0043)$ & & $(0,0058)$ & $(0,0049)$ & & $(0,0066)$ \\
\hline \multirow{2}{*}{$d G D P / f_{0}^{\prime \prime} \_p p p$} & & 0,0698 & $-0,0204$ & & & \\
\hline & & $(0,0901)$ & $(0,1192)$ & & & \\
\hline \multirow[t]{2}{*}{$d Q \_G D P / f^{\prime \prime}$} & & & & & 0,2004 & 0,1624 \\
\hline & & & & & $(0,1121)$ & $(0,1548)$ \\
\hline korrR $R^{2}$ & 0 & 0 & 0 & 0,043 & 0,083 & 0,048 \\
\hline Béta & - & & & - & & \\
\hline Felezési ido" & - & & & - & & \\
\hline
\end{tabular}

Magyarázat és jelölések: valamennyi változó az EU27 átlagához viszonyítva értendő. Függő változók (oszlopok): $d P L$ : a GDP PPP-n mért árszintjének évi átlagos változása (1-3. oszlop); $d D L$ : a GDPdeflátor évi átlagos változása (4-6. oszlop). Magyarázó változók (sorok): $P L \_95$, illetve $P L \_08:$ a GDP árszintje 1995-ben, illetve 2008-ban; d_GDP/fö_ppp, illetve dQ_GDP/fö: a GDP/fö évi átlagos növekedési üteme a PPP-n, illetve a relatív volumenindexszel mérve. Zárójelben: standard hiba; ***: $\mathrm{p}<0,01$; $* *$ : $<0,05 ; * \mathrm{p}<0,1$

Forrás: Eurostat alapján saját számítások

2. Árszintfelzárkózás. A 6. táblázat felső blokkjának 1. és 4. oszlopában látható eredmények szerint, ha az időszak kezdő évének függvényében vizsgáljuk az időszak egészében tapasztalt relatív árszintváltozást, akkor szignifikáns negatív összefüggést találunk, ennek alapján azonban tévedés lenne azt a következtetést levonni, hogy az időszak egészét árszintfelzárkózás jellemezte. Az árfelzárkózás ugyanis kizárólag a 2008-ig tartó folyamatokhoz köthető (középső blokk), a második periódusban ugyanis nincs összefüggés a relatív árszintváltozás és a 2008. évi relatív árszint között (lásd a táblázat alsó blokkját).

A reálfelzárkózáshoz kapcsolódó eredményekkel konzisztensen 2008-ig a relatív GDP-deflátorral mért árszint-konvergencia gyorsabb volt a PPP-n mértnél. A táblázat 2. és 5. oszlopában a relatív árszintváltozás és a relatív fejlettség változása közötti kapcsolatra vonatkozó eredmények is szerepelnek, amelyek nem csupán szoros összefüggést jeleznek az első időszakban, hanem azt is, hogy a volumenindexszel mért évi 1 százalékos egy före jutó GDP-növekedés a deflátorral mért évi 1,1 százalékos árszintemelkedéssel járt együtt, ami hosszabb távon aligha lehetett fenntartható. A PPP-n számított mutatók szerint viszont az árszintnövekedés üteme kissé elmaradt a GDP/fő emelkedésétől. Ezért úgy látom, hogy a deflátorok és a vo- 
A nominális felzárkózás időben változó összetevői: reálgazdasági és...

lumenindexek által jelzett folyamatok alkalmasabbak a 2008 utáni árkonvergencia elakadásának magyarázatára, mint a PPP-n mért mutatók. Ehhez hozzá kell tenni: azokban a becslésekben, amelyekben a bázisidőszaki árszint és a GDP/fö növekedése egyaránt magyarázó tényezője az árszint emelkedésének (3. és 6. oszlop), az utóbbi tényező magyarázó ereje (koefficiense és statisztikai szignifikanciája) lényegesen csökken.

3. Az árszint és a reálfelzárkózás összehasonlitása. Bármelyik mutatóval mérjük is, a 2008-ig tartó időszakban - amelyre nézve az eredmények egyáltalán összehasonlíthatók - az árszintfelzárkózás lényegesen gyorsabb volt, mint a reálgazdasági konvergencia. Az előbbi üteme 5,5-5,8 százalék, az utóbbié 3,6-4,1 százalék között alakult. Ezért indokolt lehet az az értelmezés, hogy az időszak első felét az árszintkonvergencia „túlfutása” jellemezte. Ez a feszültség a második időszakban azáltal enyhült, hogy az árszintfelzárkózás elakadt, ami pedig hozzájárulhatott ahhoz, hogy a reálfelzárkózás a korábbinál lassabban, de folytatódjon.

4. Reálgazdasági és reálméret-felzárkózás. A 5. táblázat 3. és 4. oszlopa mutatja, hogy a reálméret-felzárkózás sebessége jóval elmaradt a reálfejlettségi felzárkózásétól, vagyis az EU fejletlenebb országainak relatív népességcsökkenése technikailag hozzájárult az egy före jutó GDP-vel mért reálgazdasági felzárkózáshoz. Ezt a megállapítást a 5. táblázat 6 . oszlopában közölt eredmények is alátámasztják: a népességváltozás és a kezdeti fejlettségi szint között mindkét periódusban szignifikáns pozitív összefüggés mutatkozik: a fejlettebb országok népessége az EU átlagához viszonyítva gyorsabban nőtt, a fejletlenebbeké pedig lassabban (illetve csökkent). Ez az EU-tagországokra vonatkozó eredmény szögesen ellentétes azzal, amely a Penn World Table adatai alapján, sokkal szélesebb nemzetközi összehasonlításra (144 országot tartalmazó mintára) támaszkodva adódik: a népességnövekedés üteme szignifikáns negatív kapcsolatban van a fejlettségi szinttel. ${ }^{43}$

Végül - a teljesség kedvéért, nem pedig közgazdasági relevanciája miatt - röviden érintem az euróban mért GDP/fö, illetve GDP alapján értelmezett nominális béta konvergencia alakulását a vizsgált időszakban. Ezekben a becslésben a fenti [1] egyenlet bal oldalán az euróban mért GDP/fö bázisidőszaki relatív szintjének logaritmusa áll, jobb oldalán pedig a GDP/fö, illetve a GDP euróban mért relatív növekedési üteme. Az eredményeket a 7. táblázat tartalmazza.

A nominális felzárkózásra vonatkozó becslési eredmények - összhangban az előző két táblázatban ismertetettekkel - azt mutatják, hogy az egyidejű ár- és reál-

${ }^{43}$ Lásd Krekó \& Oblath, 2018:41-42. 
felzárkózás eredőjeként viharos sebességű volt az euróban mért szintek közeledése 2008-ig. Azt követően azonban - az árszintfelzárkózás elakadása miatt - a nominális közeledés lényegesen nagyobb mértékben lassult le, mint maga a reálfelzárkózás (akár PPP-n, akár volumenindexekkel mérjük az utóbbit). Ez csak megerősíti: a nominális mutatókat szét kell bontani ahhoz, hogy egyes időszakok, régiók és országok felzárkózási folyamatainak természetéről képet alkothassunk.

7. táblázat

Becslési eredmények: az EU27 átlagához viszonyított, euróban mért GDP/fö, illetve GDP növekedési üteme és a bázisidőszaki GDP/fö összefüggése az EU25-ben 1995 és 2019 között és két részperiódusban

\begin{tabular}{|c|c|c|}
\hline \multirow{4}{*}{$\ln (G D P / f o$ _95_eur $)$} & dGDP/fö_eur & dGDP_eur \\
\hline & \multicolumn{2}{|c|}{$1996-2019$} \\
\hline & $-0,0239 * * *$ & \multirow{2}{*}{$\begin{array}{c}-0,0219 * * * \\
(0.0023)\end{array}$} \\
\hline & $(0.0019)$ & \\
\hline \multirow{3}{*}{$\begin{array}{l}\text { korrR² } \\
\text { Béta } \\
\text { Felezési idö }\end{array}$} & 0,873 & 0,792 \\
\hline & $3,5 \%$ & $3,1 \%$ \\
\hline & 19,6 & 22,3 \\
\hline \multirow{3}{*}{$\ln (G D P / f o ̈$ _95_eur $)$} & \multicolumn{2}{|c|}{$1996-2008$} \\
\hline & $-0,0522 * * *$ & \multirow{2}{*}{$\begin{array}{c}-0,0448^{* * *} \\
(0.0080)\end{array}$} \\
\hline & $(0.0085)$ & \\
\hline \multirow{3}{*}{$\begin{array}{l}\text { korrR }{ }^{2} \\
\text { Béta } \\
\text { Felezési idö }\end{array}$} & 0,602 & 0,558 \\
\hline & $8,7 \%$ & $6,7 \%$ \\
\hline & 7,9 & 10,3 \\
\hline \multirow{3}{*}{$\ln (G D P / f o ̈$ _08_eur $)$} & \multicolumn{2}{|c|}{ 2009-2019 } \\
\hline & $-0,0173 * * *$ & \multirow{2}{*}{$\begin{array}{c}-0.0094^{* *} \\
(0,0043)\end{array}$} \\
\hline & $(0,0041)$ & \\
\hline korrR $R^{2}$ & 0,402 & 0,132 \\
\hline Béta & $1,9 \%$ & $1,0 \%$ \\
\hline Felezési idő & 36,8 & 70,2 \\
\hline
\end{tabular}

Jelölések: dGDP/fö_eur, illetve dGDP_eur: a GDP/főnek, illetve a GDP-nek az EU átlagához viszonyított, euróban mért növekedési üteme.

Forrás: Eurostat alapján saját számítások. 
A nominális felzárkózás időben változó összetevői: reálgazdasági és...

\section{5. Összegzés, tanulságok és a vizsgálat további irányai}

Írásom - bilaterális példákra, az EU-n belüli statisztikai összehasonlításokra és egyszerü ökonometriai elemzésre támaszkodva - arra hívta fel a figyelmet, hogy mind a fejlettségi különbségeket, mind pedig a fejlettségi rés zsugorodásának, vagyis a felzárkózásnak a mértékét tekintve rendkívül félrevezetők lehetnek a nominális (folyó áron, azonos valutában végzett) összehasonlítások. Ahhoz, hogy a lemaradás és a felzárkózás mértékéről és metszeteiről képet kaphassunk, az egy före jutó GDPben mutatkozó nominális szintkülönbségeket (változásaikat) árszint-, illetve reálkülönbségekre (ezek változásaira) kell bontani. Az árszint- és a reálgazdasági felzárkózás külön-külön és egymással összefüggésben egyaránt közgazdasági elemzést érdemlő jelenségek, amelyeket a nominális összehasonlítások nem szintetizálnak, hanem elfednek.

Az Európai Unióban 1995 és 2019 között tapasztalt folyamatokat vizsgálva bemutattam, hogy 2008-ig a gyors reálgazdasági felzárkózásnál lényegesen gyorsabb volt az euróban mért árszintek közeledése, vagyis a nominális felzárkózás nagyobb része árfelzárkózásnak (a fejletlenebb tagországok valutái reálfelértékelődésének) tulajdonítható. A 2008-2009. évi globális válság után azonban az árszintek közeledése elakadt (több országban a korábbi irányzat meg is fordult), miközben a reálgazdasági felzárkózás lassult, de folytatódott.

Ez intuitív módon úgy is értelmezhető, hogy a vizsgált időszak első részében az árszint-konvergencia „túlfutott” a reálfelzárkózás által indokolt mértéken (megelölegezve a reálkonvergencia töretlenségét, egyfajta buborékot létrehozva), és az így keletkezett feszültséget enyhítette vagy szüntette meg az árfelzárkózás elakadása/megfordulása, ami hozzájárulhatott a reálfelzárkózás folytatódásához. Ez az értelmezés csak az egyes országokra vonatkozó részletes elemzésekkel támasztható alá, ami a jelen munka folytatásának az egyik lehetséges iránya.

Az EU felzárkózó térségére nézve ez az értelmezés arra támaszkodik, hogy a relatív fejlettségi és árszintek közötti összefüggés csak hosszabb távon érvényesül, amelyen belül a távolodási időszakokat idővel közeledési periódusok követik. A távolodási időszakban keletkezett feszültségek enyhülésével az árszint-konvergencia folytatódására számíthatunk, amelynek elözetes jelei meg is mutatkoznak (lásd az 5. ábrát, amely azt jelzi, hogy a 2008 óta tartó szigma divergencia az árszintekben 2016 után megfordulni látszik).

Írásom megkülönböztette egymástól a gazdaságok reálméretének (GDP) és a reálfejlettségi szinteknek (GDP/fö) a felzárkózását. Bemutattam, hogy a KKEU-i 
országok reálfejlettségi felzárkózásában technikai szempontból szerepet játszott az EU átlagához viszonyított népességcsökkenés. Ez a jelenség számos olyan kérdést vet fel, amelyek tárgyalása túlmutat írásom keretein. Ezek közé tartozik a foglalkoztatottak népességen belüli arányának viszonylagos változása, így a munkatermelékenységben tapasztalt felzárkózás alakulása.

Bemutattam, hogy a reálgazdasági, illetve árfelzárkózás alternatív statisztikai források, nevezetesen a PPP-adatbázisok és a nemzeti statisztikák relatív mutatószámai alapján egyaránt értelmezhető és mérhető. Bár módszertani szempontból a nemzeti számlák ár- és volumenindexei alkalmasabbak a relatív változások mérésére, nem foglaltam egyértelmủen állást abban a kérdésben, hogy melyik mutató a jobb, mert csak a kontextus ismeretében dönthető el, hogy melyik a hihetőbb. Mivel a PPP szintbeli, a volumenindex pedig időbeli összehasonlításra szolgál, a változásokat illető jelentősebb eltérések esetén a relatív volumenindex tekinthető megbízhatóbbnak. Extrém példa Szlovákia, ahol a PPP-n mért mutatók jelezte változások kifejezetten hihetetlenek.

Nem feltétlenül kell azonban eleve állást foglalni abban a kérdésben, hogy a kettő közül melyik a jobb mutató. Számos olyan gazdasági jelenség létezik, amelyet az alternatív statisztikák eltérő módon és egymástól gyakran merőben különböző eredményeket produkálva mérnek (gondoljunk a foglalkoztatottságra, a keresetekre, a megtakarításokra vagy a nemzetgazdaság nettó külső finanszírozási képességére).

Ezeknek az analógiáknak az alapján úgy érdemes tekinteni a felzárkózási folyamatra, mint egy közvetlenül nem megfigyelhető, alternatív statisztikai módszerekkel számszerüsíthető jelenségre. Nagyobb eltérések esetén országonként külön-külön, a kontextus ismeretében lehet véleményt alkotni arról, hogy melyik mutató jelzései valószerübbek. A munka folytatásának egyik iránya éppen a PPP-n és a volumenindexekkel mért változások közötti eltérés - az összetételhatás - szerkezetének és a cserearány-változáson kívüli tényezőinek feltárása lehet.

Az, hogy a reálfelzárkózás PPP-n és relatív volumenindexszel egyaránt mérhető, lehetőséget ad a cherry-pickingre - arra, hogy a kétféle adatforrásból azokat az adatokat emeljük ki, amelyek prekoncepcióinkhoz jobban passzolnak. Ha például valakinek az a szándéka, hogy igazolja a 2010 óta tartó kormányzás sikereit, akkor a relatív volumenindexre hivatkozik, és elhallgatja, hogy az elmúlt évtizedben a megelőzőnél szerényebb volt a PPP-n mért felzárkózás. 
Végül nagy kérdés, hogy a koronavírus-járvány gazdasági következményei középtávon hogyan befolyásolják az EU-n belüli reálgazdasági és árfelzárkózási folyamatot. Az írás lezárása idején rendelkezésre álló adatok (2020. évi növekedési ütemek) erre nézve nem adhatnak eligazítást. A GDP-volumenmutatók szerint a visszaesés mértéke alapvetően a szolgáltató szektor (azon belül a turizmus) súlyától, és - vélhetően - a járvány gazdasági következményeinek kezelési módjától függ, de nincs közvetlen köze a gazdaságok fejlettségi szintjéhez (lásd az M7. ábrát az online Mellékletben). Ehhez azonban hozzá kell tenni: a járvány gazdasági következményei ár- és volumen-összetevőinek számszerüsítése szokatlan kihívást jelent mind a nemzeti adatokat továbbvezető, mind pedig a keresztmetszeti nemzetközi öszszehasonlításokért (a PPP-adatokért) felelős statisztikusok számára. Rövid idő alatt olyan mértékủ árarány- és összetétel-változások történtek, amelyeket roppant nehéz statisztikailag követni és a szokásos indexekkel leképezni. Az utókor dolga lesz a 2019-ig tartó, valamint a 2020-szal kezdődő idősorokat tartalmilag összehasonlítani és összekapcsolni. A hosszabb távú felzárkózási folyamatra vonatkozó számszerü elemzésekben egy ideig a 2019. évnél érdemes lesz megállni. 


\section{Hivatkozások}

Alcidi, C. (2019). Economic Integration and Income Convergence in the EU. Intereconomics, 54(1): 5-11. https://www.intereconomics.eu/contents/year/2019/number/1/article/economic-integrationand-income-convergence-in-the-eu.html

Asea, P. K. \& Corden, W. M. (1994). The Balassa-Samuelson Model: An Overview. Review of International Economics, 2(3): 191-200. https://EconPapers.repec.org/RePEc:bla:reviec:v:2:y:19 94:i:3:p:191-200

Balassa, B. (1964). The Purchasing Power Doctrine: A Reappraisal. 1964. Journal of Political Economy, 72(6): 584-596.

Barro, R. J. \& Sala-i-Martin, X. (2004). Economic Growth. MIT Press.

Batog, C., Crivelli, E., Ilyina, A., Jakab, Z., Lee, J., Musayev, A, Petrova, I.,Scott, A., Shabunina, A., Tudyka, A., Cindy Xu, X. \& Zhang, R. (2019). Demographic headwinds in Central and Eastern Europe. IMF, European Departmental Paper Series. No. 19. https://www.imf.org/en/Publications/ Departmental-Papers-Policy-Papers/Issues/2019/07/11/Demographic-Headwinds-in-Centraland-Eastern-Europe-46992b

Belka, M. \& Devereux, M. B. (2013). Trends in European real exchange rates. Economic Policy, 28(74): 193-242. https://doi.org/10.1111/1468-0327.12006

Berend T. I. (2020a). Délibábos Közép-Európa. Élet és Irodalom, 2020. július 3.

Berend T. I. (2020b). Válasz. Élet és Irodalom, 2020. július 17.

Bolt, J. \& Zanden, J. L. (2020). Maddison style estimates of the evolution of the world economy. A new 2020 update. Maddison-Project Working Paper WP-15. https://www.rug.nl/ggde/ historicaldevelopment/maddison/publications/wp15.pdf

Cassel, G. (1922). Money and foreign exchange after 1914. Constable and Co., New York.

Čihák, M. \& Holub, T. (2005). Price convergence in EU-accession countries: Evidence from the international comparison. Économie internationale, 102(2): 59-82. https://www.cairn.info/revueeconomie-internationale-2005-2-page-59.htm

Csillag I. \& Mihályi P. (2020). Még nagyobb a baj (válasz a Külgazdaság körkérdésére). Külgazdaság, 64(1-2): 19-24. DOI: 10.47630/KULG.2020.64.1-2.3

Daglaard, E. \& Sorensen, H. S. (2002). Consistency between PPP Benchmarks and National Price and Volume Indices. Paper prepared for the 27th General Conference of the International Association for Research in Income and Wealth, Stockholm, August.

Degler, M. \& Staehr, K. (2021). Price and income convergence and the dynamic Penn effect in Central and Eastern Europe. Economic change and Restructuring, 54(3): 621-635. https://doi.org/10.1007/ s10644-019-09248-6

Dobrescu, E. (2015). Comparative Price Level (CPL) - A Representative Parameter of economic convergence. Romanian Journal of Economic Forecasting, 18(4): 7-28. https://www.researchgate. net/publication/292394162_Comparative_price_level_CPL_-_A_representative_parameter_of_ economic_convergence

Dreger, C., Kholodilin, K., Lommatzsch, K. Kirsten, J., Jirka, S. \& Przemyslaw, W. (2007). Price convergence in the enlarged internal market. European Economy, Economic Papers No. 292. November. http://www.case-research.eu/sites/default/files/publications/18471306_rap76_0.pdf

ECB (2015). Real convergence in the euro area: Evidence, theory and policy implications. ECB Economic Bulletin, Issue 5. https://www.ecb.europa.eu/pub/pdf/other/eb201505_article01.en.pdf

Eichengreen, B. (2019). Convergence and Divergence in the EU: Lessons from Italy. Intereconomics, 54(1): 31-34. https://www.intereconomics.eu/contents/year/2019/number/1/article/convergenceand-divergence-in-the-eu-lessons-from-italy.html

Eurostat (2020a). Database: Purchasing power parities (PPPS), price level indices and real expenditures for ESA 2010 aggregates. https://appsso.eurostat.ec.europa.eu/nui/submitViewTableAction.do

Eurostat (2020b). Database: Annual national accounts. Main GDP aggregates. 
Eurostat \& OECD (2012). Eurostat-OECD Methodological Manual on Purchasing Power Parities. Eurostat Methodologies and Working papers https://ec.europa.eu/eurostat/ documents/3859598/5923225/KS-RA-12-023-EN.PDF/e2755b1b-68a5-4dad-86f5-6327c76da14d

Feenstra, R. C., Inclaar, R. \& Timmer, M. P. (2015). The Next Generation of the Penn World Tables. American Economic Review, 105(10): 3150-3182. DOI: 10.1257/aer.20130954b

Fellegi T. (2021). Mekkora a magyar GDP felzárkózása a rendszerváltás óta? https://novekedes.hu/ elemzesek/mekkora-a-magyar-gdp-felzarkozasa-a-rendszervaltas-ota

Franks, J., Barkbu, B., Blavy, R., Oman, W. \& Schoelermann, H. (2018). Economic Convergence in the Euro Area: Coming Together or Drifting Apart? IMF Working Paper, WP/18/10. https://www.imf. org/en/Publications/WP/Issues/2018/01/23/Economic-Convergence-in-the-Euro-Area-ComingTogether-or-Drifting-Apart-45575

Győrffy D. (2021). Felzárkózási pályák Kelet-Közép-Európában két válság között. Közgazdasági Szemle, 68(január): 47-75. DOI: http://dx.doi.org/10.18414/KSZ.2021.1.47

Halmai P. (2019). Konvergencia és felzárkózás az euróövezetben. Közgazdasági Szemle, 66(június): 687-712. DOI: http://dx.doi.org/10.18414/KSZ.2019.6.687

Heady, D. D. \& Hodge, A. (2009). The effect of population growth on economic growth: A metaregression analysis of the macroeconomic literature. Population and Development Review, 35(2): 221-248. https://doi.org/10.1111/j.1728-4457.2009.00274.x

Kónya I. (2018). Economic Growth in Small Open Economies. Palgrave Macmillan, Cham.

Kónya I., Krekó J. \& Oblath G. (2020). Labor shares in the old and new EU member states - sectoral effects and the role of relative prices. Economic Modelling, 90: 254-272. https://doi.org/10.1016/j. econmod.2020.05.010

Krekó J. \& Oblath G. (2018). Economic Convergence and Exchange Rate Misalignments in the European Union. MTA KRTK KTI Discussion Papers, No. 2018/25 https:/www.econstor.eu/ bitstream/10419/222038/1/dp2018-25.pdf

Krekó J. \& Oblath G. (2020). Economic growth and real exchange rate misalignments in the European Union. Acta Oeconomica, 70(3): 297-332. https://doi.org/10.1556/032.2020.00016

Matić, M. G., Gavrilović, B. J. \& Stanišić, N. (2020). GDP and beyond: Prosperity convergence in the countries of Western and Eastern Europe. Acta Oeconomica, 70(4): 493-511. DOI: 10.1556/032.2020.00033

McCarthy, P. (2013). Extrapolating PPPs and Comparing ICP Benchmark Results. In: World Bank (2013), Chapter 18: 473-505.

MPD (2020). The Maddison Project Database. https://www.rug.nl/ggdc/historicaldevelopment/ maddison/releases/maddison-project-database-2020?lang=en

Oblath G. \& Palócz É. (2020). Gazdasági növekedés, fogyasztás és megtakarítás Magyarországon az elmúlt évtizedben. In: Kolosi Tamás, Szelényi Iván, Tóth István György (szerk.): Társadalmi Riport 2020, TÁRKI, Budapest. 39-59. https://www.tarki.hu/sites/default/files/2020-10/039_059_ OblathG_Palocz_web.pdf

Oblath G. (2013). Hány év múlva? - A konvergencia természetéről és időigényéről. Statisztikai Szemle, 91(10): 925-946. http://real.mtak.hu/7795/1/2013_10_925.pdf

Oblath, G. (2014a). Felzárkóztak az árak és lemaradtak a bérek? Tévhitek, tények és közgazdasági összefüggések. Statisztikai Szemle, 92(8-9): 745-765. https://www.ksh.hu/statszemle_archi ve/2014/2014_08-09/2014_08-09_745.pdf

Oblath. G. (2014b). Gazdasági átalakulás, nekilendülés és elakadás: Magyarország makrogazdasági konvergenciája az Európai Unió fejlett térségéhez az 1990-es évek elejétől 2013-ig. In: Kolosi T., Tóth I. Gy. (szerk.): Társadalmi Riport 2014. TÁRKI, Budapest, 21-50. https://tarki.hu/ adatbank-h/kutjel/pdf/b323.pdf

Oblath G. (2019a). Külkereskedelmi cserearányok, bruttó hazai reáljövedelem és bruttó hazai termék: változások és szintek nemzetközi összehasonlításban. KRTK Közgazdaságtudományi Intézet Múhelytanulmányok MT-DP 2019/17. http://real.mtak.hu/102232/1/MTDP1917.pdf 
Oblath G. (2019b). Külkereskedelmi cserearány-változások és hatásuk a bruttó hazai reáljövedelemre, a belföldi felhasználásra és a jövedelmi felzárkózásra. Külgazdaság, 63(11-12): 3-41. DOI: https:// doi.org/10.47630/KULG.2019.63.11-12.3

Oblath G. (2020). A relativ fejlettség szintjének és a fejlettség szintjének relativ változása. KRTK KTI Blog. https://www.mtakti.hu/blog/oblath-gabor-a-relativ-fejlettseg-szintjenek-es-a-fejlettsegszintjenek-relativ-valtozasa/12648/

Oblath G., Palócz É., Popper D. \& Valentinyi Á. (2015). Economic convergence and structural change in the new member states of the European Union. Discussion Paper No. 2015/44, Institute of Economics, Centre for Economic and Regional Studies, Hungarian Academy of Sciences. https:// www.econstor.eu/handle/10419/129858

OECD (2020). Database: Purchasing Power Parities for GDP and related indicators. https://stats. oecd.org/Index.aspx

Peterson, E. W. F. (2017). The Role of Population in Economic Growth. SAGE Open, 7(4). https://journals. sagepub.com/doi/full/10.1177/2158244017736094 https://doi.org/10.1177/2158244017736094

PWT (2021). The Penn World Table version 10.0. https://www.rug.nl/ggdc/productivity/pwt/?lang=en

Samuelson, P. (1964). Theoretical Notes on Trade Problems. Review of Economics and Statistics, 46(2): 145-154. https://doi.org/10.2307/1928178

Samuelson, P. (1994). Facets of Balassa-Samuelson Thirty Years Later. Review of International Economics, 2(3): 201-226. https://doi.org/10.1111/j.1467-9396.1994.tb00041.x

Simonovits A. (2020a). A felzárkózás matematikája. Élet és Irodalom, 2020. július 10.

Simonovits A. (2020b). A gazdasági fejlettségröl. Élet és Irodalom, 2020. szeptember 4.

Vincze J. (2018). Szubsztantív vagy ökológiai racionalitás? A pénzillúzió esete. Közgazdasági Szemle, 65(november): 1097-1114. https://doi.org/10.18414/KSZ.2018.11.1097

World Bank (2013). Measuring the Real Size of the World Economy: The Framework, Methodology, and Results of the International Comparison Program - ICP. Washington, DC. doi: 10.1596/9780-8213-9728-2

World Bank (2021). International Comparison Program (ICP). https://www.worldbank.org/en/ programs/icp 